University of Rhode Island

DigitalCommons@URI

Open Access Master's Theses

1991

\title{
DEOXYRIBONUCLEIC ACID CHARACTERIZATION OF THREE SPECIES OF DIATOMS WITHIN GENUS THALASSIOSIRA
}

Robert D. Vaillancourt

University of Rhode Island

Follow this and additional works at: https://digitalcommons.uri.edu/theses

\section{Recommended Citation}

Vaillancourt, Robert D., "DEOXYRIBONUCLEIC ACID CHARACTERIZATION OF THREE SPECIES OF DIATOMS WITHIN GENUS THALASSIOSIRA" (1991). Open Access Master's Theses. Paper 1295. https://digitalcommons.uri.edu/theses/1295

This Thesis is brought to you for free and open access by DigitalCommons@URI. It has been accepted for inclusion in Open Access Master's Theses by an authorized administrator of DigitalCommons@URI. For more information, please contact digitalcommons-group@uri.edu. 
DEOXYRIBONUCLEIC ACID CHARACTERIZATION OF THREE SPECIES OF DIATOMS WITHIN THE GENUS IHALASSIOSIRA

BY

ROBERT D. VAILLANCOURT

A THESIS SUBMITTED IN PARTIAL FULFILLMENT OF THE REQUIREMENTS FOR THE DEGREE OF

MASTER OF SCIENCE

IN

OCEANOGRAPHY

UNIVERSITY OF RHODE ISLAND 


\section{MASTER OF SCIENCE THESIS \\ OF}

ROBERT D. VAILLANCOURT

APPROVED:

Thesis Committee

Major Professor

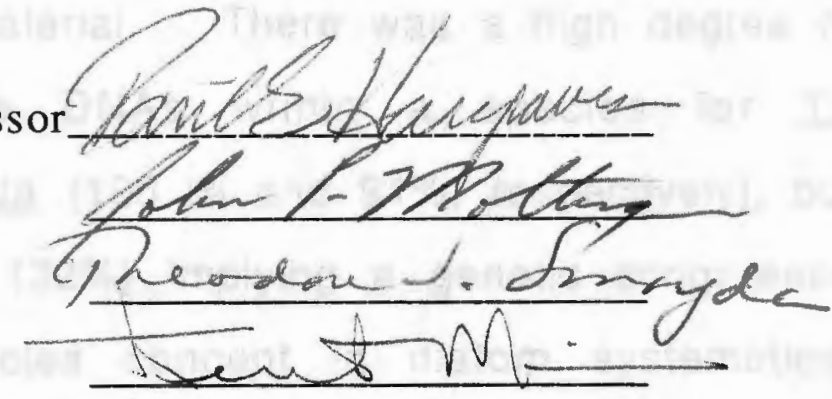

DEAN OF THE GRADUATE SCHOOL 


\section{Abstract}

A comparison was made of the lengths of the restriction fragments produced when total DNA from eight clones of three species of diatoms, Ihalassiosira rotula (Meunier), I gravida (Cleve) and Inordenskioeldii (Cleve), was digested with twelve restriction endonucleases and probed with two heterologous chloroplast DNA probes from $c_{\text {reinhardtii. }}$ DNA from the I rotula clones would not hybridize with the $\mathrm{C}$ reinhardtii probes under high stringency conditions but the I gravida and I nordenskioeldii DNA hybridized strongly to these same probes. The most likely reason for lack of hybridization with I rotula DNA is its contamination with high amounts of polysaccharide material. There was a high degree of molecular similarity in the DNAs within a species for $I$. nordenskioeldii and I gravida (100\% and $91 \%$, respectively), but much less between species (32\%) implying a genetic congruence with the morphological species concept in diatom systematics. Genetic similarity between and within species is based on the probe detection of 44 restriction fragments, or 264 DNA bases which comprise $0.18 \%$ of the entire chloroplast genome, estimated at 147 kilobase pairs. 


\section{Acknowledgements}

The multidisciplinary nature of this research demanded and benefited from the participation of many. Paul Hargraves offered much financial and moral support throughout my master's tenure, especially in allowing me the initial opportunity to come to GSO. I thank Jan Rines for her friendship and help in learning how to jump through the hoops most efficiently. John Mottinger and Sharon Lee of the Botany department opened their lab to me and thereby helped pioneer the merger of molecular biology and oceanography at GSO by supplying the necessary technical advice, instrumentation and supplies. Ted Smayda offered many insightful comments concerning the biogeography of diatoms and Richard Steele at the EPA lab offered much help in mass culturing in the early stages of this investigation. Joe Stabile of City College of New York and Robert Jansen of the University of Connecticut gave much needed advice and rigorous criticism of my initial naive ideas of molecular DNA systematics. Financial support for this project was provided by the GSO Alumni Fund and the oceanography scholarship awarded to me by the radio station WWRX, Providence and Westerly.

And finally, I acknowledge the assistance, encouragement and love of my wife, Beverley, whose friendship and unwavering support enables me to lead a more balanced existence and gives me the strength each day to wage battle with the evil forces of entropy. And to my incorrigible daughter, Doreen, who continues to frighten me each day with her seemingly firm grasp of the world's subtleties. I thank her simply for being a happy and good person regardless of how unreasonable and nasty her father sometimes becomes. 


\section{Table of Contents}

I ) APPROVAL PAGE .....................................................................................

II ) ABSTRACT …………………………………………………………... ii

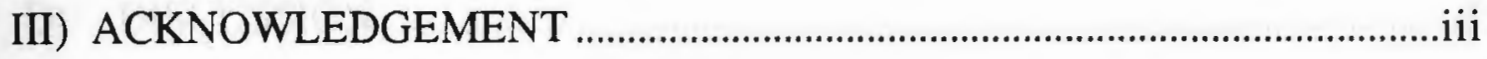

IV) TABLE OF CONTENTS .......................................................................iv - v

V) LIST OF TABLES ……………………………………………………....

VI) LIST OF FIGURES ..................................................................................... vii

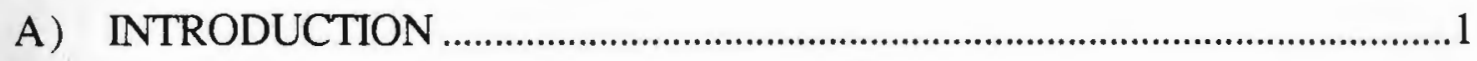

B) METHODS AND MATERIALS ......................................................................

1.) Taxonomy ……………………………………………………....

2.) Diatom Culturing ..............................................................................

3.) Harvesting ...........................................................................................

4.) Cell Lysis and Total DNA Extraction ..........................................

5.) Chloroplast DNA isolation...........................................................11

6.) Restriction Enzyme digestion of DNA......................................12

7.) Agarose Gel Electrophoresis.........................................................12

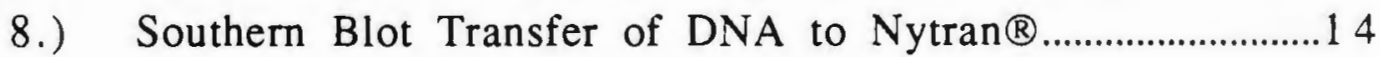

9.) Preparation of the gene probe..................................................14

10.) Oligolabeling of probe DNA with 32 P-ATP ...........................15

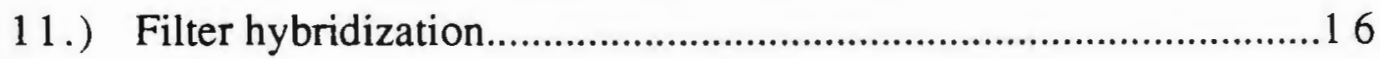

12.) DNA Quantification by Fluorescence .........................................1 17

13.) Protein Determination..................................................................... 18

14.) Polysaccharide Determination ...................................................18

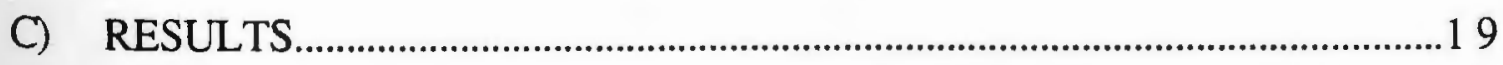

1.) Estimates of chloroplast genome size for $\mathrm{T}$. rotula............25 
2.) Estimates of Total DNA content per Cell...............................26

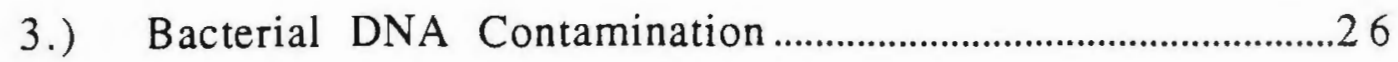

4.) Restriction Enzyme Analysis .................................................22

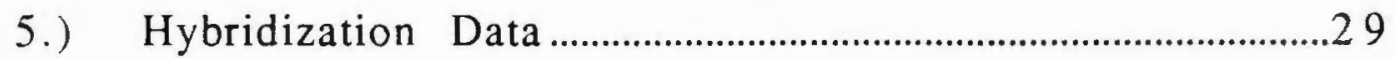

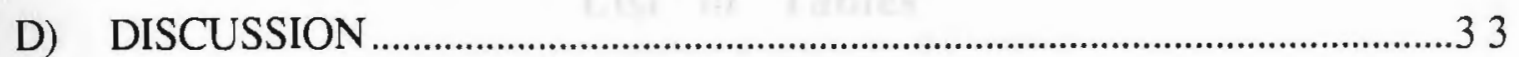

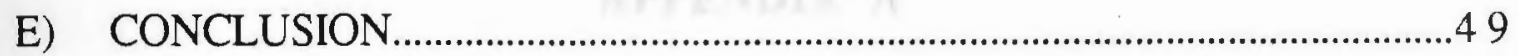

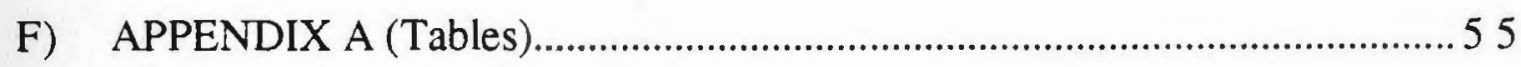

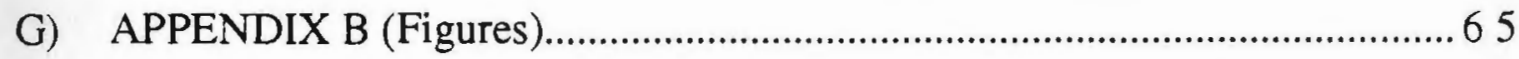

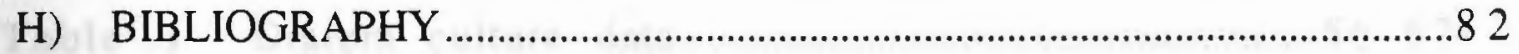




\section{List of Tables \\ APPENDIX A}

Table 1 Diatom culture data ......................................................56-57

Table 2 Summary of Purification steps for diatom clones and some relevant data............................................58

Table 3 Chemical characterization of diatom total DNA ...............59

Table 4 List of number and size of diatom DNA restriction fragments produced with ten restriction enzymes $60-61$

Table 5 Data from autoradiographs of figures 7 and 8 62

Table 6 Similarity matrix tables......................................................6

Table 7 Predicted cell carbon and DNA estimates from mensuration and empirical formulae. 64 


\section{List of Figures}

\section{APPENDIX B}

Figure 1 Standard deviation of fragment mobilities...............67-68

Figure 2 Agarose gel of diatom total DNA incubated with and without RNase A................................................68-69

Figure 3 UV spectra of diatom total DNA samples..................70-71

Figure $4 \mathrm{CsCl}$ - Hoechst dye gradient figures.............................72-73

Figure 5A Agarose gel of $\mathrm{T}$ rotula DNA fractions from $\mathrm{CsCl}$ gradient

$.74-75$

Figure 5B Autoradiograph of gel in figure 5A...........................74-75

Figure 6 Agarose gel of $\underline{T}$ rotula cpDNA digest.........................76-77

Figure 7 Autoradiographs of diatom DNA gels showing bands homologous to $\underline{C}$. reinhardtii cpDNA probe for 23s rDNA gene …………………………….....78-79

Figure 8 Autoradiographs of diatom DNA gels showing bands homologous to $C$. reinhardtii cpDNA probe for $r b c L$ gene $80-81$ 


\section{INTRODUCTION}

The marine diatoms Ihalassiosira gravida (Cleve) and I rotula (Meunier) exhibit a mutually exclusive distribution in the Pacific and Atlantic Oceans with some overlap. I gravida is found in high latitudes of both hemispheres from about $70^{\circ}$ to $80^{\circ}$ down to approximately $30^{\circ} \mathrm{S}$ and $\mathrm{N}$ and I rotula occupies the low latitudes approximately between $30^{\circ} \mathrm{S}$ and $\mathrm{N}$ (Hasle 1976). Specific morphologies characterize each species in their respective biogeographical zones, but transitional morphotypes are seen at the latitudes where the two species overlap (Syvertsen 1977). These observations along with physiological studies of $I$ rotula and $I$. gravida in culture, varying temperature and nutrient concentrations (Syvertsen 1977), have cast doubt on whether I rotula and I gravida are indeed distinct species. To add to the biogeographical and morphological evidence, this research will attempt to determine if clones of each species are genetically distinguishable by restriction fragment analysis of their chloroplast DNA (cpDNA).

One method of genetically determining if there are distinct lineages for these species, and thereby prove (or disprove) that they are evolving along separate lines, is to compare the relative chloroplast DNA (cpDNA) nucleotide sequences. cPDNA is a very slowly evolving genome (Palmer 1985a; Palmer 1985b; Palmer 1987) and therefore is an ideal molecular marker for determining relative evolution of genomes between and within species. Comparative cPDNA sequence analysis has been used to determine taxonomic 
affinities between species of land plants such as the genera Clarkia (Sytsma and Gottlieb 1986), Lisianthius (Sytsma and Schaal 1985), Lycepersicon (Palmer and Zamir 1982), to determine interspecies, intergenus and interfamilial taxonomic affinities in several kelp genera (Fain 1987), interspecies relationships within the centric diatom genus cyclotella (Bourne et al. 1987), intraspecies and interspecies relationships in the diatom genera Coscinodiscus and edontella (Kowallik 1990), several red algae species (Goff and Coleman 1988) and the brown algae genera, Pylaiella and Sohacelaria (Dalmon et al. 1983), and to differentiate physiological races within the diatom genus Skeletonema (Stabile et al. 1990).

The method of cPDNA analysis used in this study was restriction fragment length polymorphisms (RFLP), a technique of measuring genetic relatedness between organisms by comparing the size of DNA fragments produced upon digestion with restriction endonucleases. Restriction endonuclease enzymes recognize and cleave at specific double stranded DNA sequences of four to eight bases within the genome. The number of fragments produced depends on how many times that specific sequence appears in the DNA and the size of the fragments produced will depend on the relative positions of the numerous restriction sites. The variability of the fragment pattern produced when two or more DNA samples are digested with the same enzyme, will reflect the variability in the DNA sequence at those specific sites. When this analysis is done with many different enzymes, each specific for a different 
nucleotide sequence, a comparison of the resulting fragment patterns will reflect the degree of genetic relatedness.

In this study, cloned cpDNA gene sequences from highly conserved areas of the chloroplast genome of the chlorophyte Chlamydomenas reinhardtii were used to probe restriction enzyme digests of total DNA from multiple clones of I rotula and I. gravida. I nordenskioeldii, a species which is morphologically distinct from both I gravida and I rotula, were used for comparison. The restriction fragment length polymorphisms generated from these analyses indicates the degree of genetic relatedness on the intra- and the interspecies level within this genus, for these three species.

\section{METHODS AND MATERIALS}

\section{Taxonomy}

The Thalassiosira nordenskioeldii and I rotula clones used in this study were identified under the phase contrast microscope first as live chains of cells in natural assemblage taken from net tows from Narragansett Bay, Rhode Island, Hull Bay, Massachusetts and Friday Harbor, Washington. The I rotula clone from Friday Harbor (clone F4) was kindly provided by Jan Rines. Once a pure culture of a suspected I rotula or I nordenskioeldii species was obtained, final identification was accomplished by observing the valve structure of hydrogen peroxide - cleaned frustules using high power, oil immersion, phase contrast microscopy. The I gravida clones used were obtained as pure cultures from the Provasoli - 
Guillard Center for Culture of Marine Phytoplankton, West Boothbay Harbor, Maine. The species identification for I gravida was also verified by observing valve morphology of cleaned material.

Ihalassiosira rotula Meunier, is identified in live mounts as chains of disk-shaped cells with one or two thickened girdle bands, more noticeable in cells devoid of organic material (Lebour 1930; Meunier 1910). The connecting strand is thicker than in most species of Thalassiosira due to the numerous threads composing this strand. Seen in valves cleaned of organic material and mounted in resin are numerous central strutted processes, a single row of strutted processes at the margin and ribs of areolae, lacking tangential walls, radiating from the center. A single labiate process is located at the margin. In valve view, some isolated girdle bands appear "unevenly thickened" due to the presence of a septum on the internal side of the intercalary band. These bands also appear "unevenly broadened" in girdle view (Meunier 1910; Syvertsen 1977). I rotula belongs to the group of Ihalassiosira with the greater length of the processes on the external side of the valve and a single marginally located labiate process (Hasle 1968).

Cells of Thalassiosira gravida Cleve have been described as being less flattened in girdle view, and lacking the "unevenly thickened" girdle bands typical of I rotula (Cleve 1896; Meunier 1910; Syvertsen 1977). In valve view of cleaned, mounted material, I gravida is in all ways similar to I rotula except for the well developed radial areola possessing tangential walls and thus eliminating the "ribbed" appearance (Hasle 1968). 
Cells of Thalassiosira nordenskioeldii Cleve are quite different in appearance from both I gravida and I rotula. The most contrasting features are the single central strutted process and the exaggerated external length of the strutted processes on the valve margin. Other identifying features are the concavity in the center of the valve, the wide mantle with beveled valve margin, and a single, marginally located labiate process (Hasle 1978). Measurements of position and number of valve features on all three clones of $I$ nordenskioeldii used in this study conform to the numerical morphological data tabulated by Syvertsen (Syvertsen 1984) to distinguish this species from several which are very similar, including: I allenii, I angulata, I decipiens. I minima. I pacifica, and $I$ hispida.

\section{Diatom Culturing}

Diatom cultures of Ihalassiosira rotula and I nordenskioeldii were collected using either a 64- or 32-micrometer mesh cod-end net. Concentrated phytoplankton samples were then diluted in sterile Narragansett Bay seawater and individual chains of Ihalassiosira picked out using a drawn-out pasteur pipet and an Olympus inverted compound microscope. Selected chains of cells were sequentially washed in sterile seawater before being carefully pipeted into seawater enriched to $f / 10$ concentration according to the protocol of Guillard and Ryther (Guillard and Ryther 1962). Subsequent transfers were made into $f / 2$ enriched seawater. I gravida cultures were obtained from the Provasoli-Guillard Center 
for Culture of Marine Phytoplankton, West Boothbay Harbor, Maine. All cultures were maintained in $10 \mathrm{ml}$ tubes in $\mathrm{t} / 2$ enriched Rhode Island Sound seawater at constant temperature $\left(+\right.$ or $\left.-1^{\circ} \mathrm{C}\right)$ and a 12:12 light-dark cycle. (see table 1.). Photon flux measurements were taken with a LiCor radiometer, model Li185A, with a Quantum sensor. Cell counts were performed using diluted lugol's preserved aliquots of concentrated mass cell cultures in $1.0 \mathrm{ml}$ SedgwickRafter counting chamber. At least 400 cells were counted in multiple horizontal paths across the chamber and the total number of cells was calculated based on the relative volumes of the paths and chamber. The cells were considered to be evenly distributed if the relative standard deviation of the horizontal path counts was less than ten percent.

Scale-up of cultures proceeded from the $10 \mathrm{ml}$ maintenance culture to a one liter and finally into a $20 \mathrm{~L}$ carboy culture. Cells in the $10 \mathrm{ml}$ culture, before being transferred into the one liter flask, were observed under low power compound microscope to ascertain the health and extent of bacterial contamination of culture. If considerable bacterial contamination existed, or if the morphology of the cells indicated less than reasonably good health, then transfers into fresh $\mathrm{f} / 2$ media in $10 \mathrm{ml}$ tubes was continued until a robust, healthy culture was obtained. At this point, the entire $10 \mathrm{ml}$ culture was transferred, aseptically, into one liter of the same media. Compressed, 0.2 micron-filtered air was bubbled through a sterile pipet into these flasks to keep the cells in suspension. When these cultures reached a high density, at least $0.5 \mathrm{~L}$ was used to 
inoculate the $20 \mathrm{~L}$ carboys of $f / 2$ enriched seawater which were also bubbled with sterile filtered, compressed air. These cultures were harvested also when a high density of cells was reached. $1 \mathrm{~L}$ and $20 \mathrm{~L}$ liter culturing was done in a separate walk-in incubator room with temperature control (+or- $1^{\circ} \mathrm{C}$ ) and $24: 0$ L:D cycle.

\section{Harvesting}

When cultures were ready to be harvested, bubbling was stopped and carboys were wrapped in black plastic: After 1 to 4 days the majority of the cells had settled to the bottom of the carboy and the seawater could be siphoned out. The volume of the resulting thick diatom "sludge" was measured and a subsample diluted into sterile-filtered seawater and preserved in Lugol's was saved for later observation and cell counts. The remaining condensate was further concentrated by centrifugation in a high speed centrifuge at 3000 to $5000 \mathrm{rpm}$ for ten minutes at $4^{\circ} \mathrm{C}$. The resulting pellet of diatoms was resuspended in the appropriate lysis buffer.

\section{Cell Lysis and Total DNA Extraction}

The DNA purification methods used in this study are a modification of the methods used by Joe Stabile at City College of New York for population genetics studies on Skeletonema costatum (Stabile, 1988 ). Nucleic acid was purified from Thalassiosira clones as total DNA including, presumably, nuclear, mitochondrial and chloroplast genomes. In some cases a chloroplast-enriched fraction was obtained from this total DNA isolate. 
The diatom pellet from a 20 to 60 liter culture was resuspended in 50 to $100 \mathrm{ml}$ of $1 \mathrm{X}$ Lysis Buffer $(350 \mathrm{mM} \mathrm{NaCl}, 10 \mathrm{mM}$ Tris-HCl, $\mathrm{pH} 7.6,1 \mathrm{mM}$ EDTA, $\mathrm{pH} 8.0$ ) with $0.2 \%$ DTT and $0.1 \%$ DMSO. This and all subsequent steps were carried out at $4^{\circ} \mathrm{C}$ or lower. The cell suspension was lysed in a french press at 1500 to 5000 psi, depending on the cell type and its degree of silicification. Cell rupture was monitored with a light microscope. If insufficient numbers of cells were broken, the procedure was repeated a second time at the same pressure. Sufficient cell rupture was considered to be approximately at least $75 \%$ of cells when viewed under light microscope. The cell lysate was centrifuged in a high speed centrifuge at 3000 to $5000 \mathrm{rpm}$ for ten minutes at $4^{\circ} \mathrm{C}$ and the supernatant poured off (purification step $\# 1$, table 2 ). The pellet contained all intact chloroplasts as well as many other cell organelles but probably excluded most soluble nuclear DNA, RNA, protein, polysaccharides and most bacteria. Approximately 2 to 3 volumes of $1 X$ Final Lysis buffer ( $20 \% \mathrm{v} / \mathrm{v}$ 10x lysis buffer, $42 \% \mathrm{w} / \mathrm{v}$ urea, $6.25 \% \mathrm{v} / \mathrm{v}$ buffered phenol, $100 \mathrm{mM}$ EDTA, pH 8, 2\% w/v Na sarkosyl, $0.2 \% \mathrm{w} / \mathrm{v} \mathrm{DTT}$, and $0.1 \% \mathrm{w} / \mathrm{v} \mathrm{DMSO}$ ) was used to resuspend the pellet and $2 \mathrm{ml}$ Triton X-100 was added to lyse the membranebound organelles. This slurry was shaken gently, on ice, for $10 \mathrm{~min}$. Chloroplast lysis was verified microscopically by the absence of visible chloroplasts. The lysate was then extracted twice with phenol/chloroform (1:1) and centrifuged at $5000 \mathrm{rpm}$ for $10 \mathrm{~min}$ in a high speed centrifuge. The aqueous phase, normally a pale purple color, was extracted one more time with a 24:1 solution 
ofchloroform/isoamyl alcohol to remove any traces of phenol and to further deproteinize the sample. To precipitate nucleic acid from this aqueous cell extract, $1 / 10$ volume of $3 \mathrm{M} \mathrm{NaAc}$ and 2 volumes of $100 \%$ cold ethanol were added and the solution placed at $-20^{\circ} \mathrm{C}$ overnight. The resulting white precipitate was centrifuged to a pellet, dried down under vacuum, washed once with $70 \%$ ethanol, and dried once more. The dried pellet was reconstituted in $0.5 \mathrm{ml}$ of Tris-EDTA (10mM Tris- $\mathrm{HCl}, \mathrm{pH} 8.0,1 \mathrm{mM} \mathrm{Na}$ EDTA) and stored at $4^{\circ} \mathrm{C}$. This solution contained predominantly RNA with the nuclear and chloroplast DNA constituting a minor component. There was also considerable protein contamination. Further purification was achieved by incubating with RNase, a RNA-digesting enzyme $\left(100 \mathrm{ug} / \mathrm{ml}\right.$ final concentration, $37^{\circ} \mathrm{C}$ for $1 \mathrm{hr}$ ) and Proteinase $\mathrm{K}$, a protein-digesting enzyme ( $500 \mathrm{ug} / \mathrm{ml}$ final concentration, 1-2\% SDS; $65^{\circ} \mathrm{C} 1 \mathrm{hr}, 37^{\circ} \mathrm{C} 2 \mathrm{hrs}$ ) and extracting twice with phenol-chloroform and once with chloroform-isoamyl alcohol (purification step \#4, table 2). The nucleic acid was reprecipitated by adding $0.04 \mathrm{X}$ volume $5 \mathrm{M} \mathrm{NaCl}$ and $2 \mathrm{X}$ volume $100 \%$ cold ethanol and stored overnight at $20^{\circ} \mathrm{C}$. The RNase and Proteinase $K$ treatments were optional and did not always seem to significantly improve the quality of the DNA in terms of restriction analysis. Total DNA was further purified from the contaminating RNA by ethidium bromide- $\mathrm{CsCl}$ isopycnic ultracentrifugation (purification step \#7, table 2). $5 \mathrm{~g}$ of molecular biology grade solid $\mathrm{CsCl}$ was added to $5 \mathrm{ml}$ of nucleic acid resuspended in TE. Ethidium bromide $(515 \mathrm{ul}$ of $10 \mathrm{mg} / \mathrm{ml})$ was added to this solution. After the $\mathrm{CsCl}$ was dissolved the solution was loaded into a $12 \mathrm{ml}$ Beckman heat sealable, polyallomer 
ultracentrifuge tube. It was necessary to fill the remaining tube volume with lower density parafin oil to prevent the tube from collapsing under the extreme g-forces of ultracentrifugation. The centrifugation was at $40,000 \mathrm{rpm}$ for 40 hours at $20^{\circ} \mathrm{C}$ in a Beckman $80 \mathrm{Ti}$ rotor and Beckman ultracentrifuge. Under these conditions a gradient formed which banded the total DNA about midway in the tube while most of the RNA formed a pellet. The DNA band was removed either through the side of the tube using an hypodermic syringe and 22 gauge needle, or from the top using a pasteur pipet. The ethidium bromide was removed by several extractions with $\mathrm{CsCl}$-saturated isopropanol or butanol and then diluted 3-fold with de-ionized water and precipitated; as previously described, with $100 \%$ cold ethanol.

Approximate concentration and purity of DNA solutions were estimated by absorbance at 260 and $280 \mathrm{~nm}$ on a Varian DMS 90 dual beam spectrophotometer (purification steps \#2, 5, 8 and 11, table 2). An absorbance value at $260 \mathrm{~nm}$ of 1.0 in a $1.0 \mathrm{~cm}$ cuvette is equal to a DNA concentration of $50 \mathrm{ug} / \mathrm{ml}$ or an RNA concentration of $40 \mathrm{ug} / \mathrm{ml}$ (Berger and Kimmel 1987). Since absorbance at A280 is proportional to protein concentration (tryptophan and tyrosine amino acids absorb radiation at $280 \mathrm{~nm}$ ) the $A_{260} / A_{280}$ ratio is then an indicator of relative purity of nucleic acid solutions (purification steps $3,6,9$ and 12 , table 2). A DNA solution is considered relatively pure if this ratio is 1.80 to 1.90 or for an RNA solution, 1.9 to 2.0. The ratio is lowered, then, by protein contamination and increased by an excess of RNA. Since the accurate conversion of 
A260 units to DNA concentration is dependents upon the purity of the solution, any converted concentration value would be suspect if the $A_{260} / A_{280}$ ratio were not 1.8 to 1.9. Therefore, except where otherwise noted, nucleic acid concentrations were reported in terms of total $A_{260}$ units as follows:

\section{$A_{260} \times$ dilution factor $\times \operatorname{Vol}(\mathrm{ml})=$ total $A_{260}$ units}

Ultraviolet spectral analysis of the DNA samples was also done on the Varian DMS 90 spectrophotometer scanning a 100 nanometer range from $300 \mathrm{~nm}$ to $200 \mathrm{~nm}$ with a slit width of one nanometer. Concentrated DNA samples were diluted in $T_{10} E$ into a one centimeter quartz cuvette stoppered with Parafilm and inverted several times to mix. The instrument was zeroed to this $T_{10} E$ buffer at $300 \mathrm{~nm}$ and there was no significant drift through the $100 \mathrm{~nm}$ range.

\section{Chloroplast DNA isolation}

In some cases the cpDNA was isolated from the total DNA recovered from the $\mathrm{CsCl-ethidium} \mathrm{bromide} \mathrm{gradient,} \mathrm{from} \mathrm{the} \mathrm{total}$ nucleic acid (before $\mathrm{CsCl}$-ethidium bromide step) or from whole cell and chloroplast lysate, by $\mathrm{CsCl}$-Hoechst dye isopycnic ultracentrifugation (purification step \#10, table 2) (Aldrich and Cattolico 1981; Fain et al. 1988; Goff and Coleman 1988). Ninety percent wt/final vol. of solid $\mathrm{CsCl}$ was added to the appropriate nucleic acid solution along with $40 \mathrm{ul}$ of a $50 \mathrm{ug} / \mathrm{ul}$ solution ( $=2 \mathrm{mg}$ ) of Hoechst dye 33258 (Sigma) in a $12 \mathrm{ml}$ Beckman polyallomer heatsealable ultracentrifuge tube, topped off with parafin oil. The 
centrifugation was for 48 hours at $40,000 \mathrm{rpm}$ at $20^{\circ} \mathrm{C}$ in a Beckman Ti80 rotor. The bands were removed and purified from dye and cesium chloride as described previously for the ethidium bromide gradients.

\section{Restriction Enzyme digestion of DNA}

Samples of 1 to $8 \mathrm{ug}$ of DNA were digested with 5 to 10 units of the appropriate restriction enzyme. RNase $(1 \mathrm{mg} / \mathrm{ml}, 1 \mathrm{mM}$ tris $\mathrm{pH} 7.5,1.5 \mathrm{mM} \mathrm{NaCl}$ ) was added to a final concentration of 100 $\mathrm{ng} / \mathrm{ul}$ to digest away contaminating RNA and a 10X concentration of assay buffer, specific for the restriction enzyme used, was added to a final concentration of $1 X$. The assay buffers were those recommended by the manufacturer. In some cases a universal buffer, "One-Phor-All Plus" (Pharmacia) was used at a $1 X$ or $2 X$ final concentration. Spermidine, to a final concentration of $5 \mathrm{mM}$, was also added. It is thought that spermidine increases the efficiency of restriction digests, although there was no difference found in digests with or without the addition of spermidine. De-ionized water was added to make all final reaction volumes 10 to $20 \mathrm{ul}$. Incubations were at $37^{\circ} \mathrm{C}$ for at least 2 hours and then loading dye was added to terminate reaction and to increase the density of the solution and facilitate its loading onto the agarose gel.

\section{Agarose Gel Electrophoresis}

Neutral agarose horizontal slab gels consisting of 0.7 or $0.8 \%$ agarose (Sigma, type I, Low EEO) in TAE buffer ( $40 \mathrm{mM}$ Trisacetate, $1 \mathrm{mM}$ EDTA) were cast with $250 \mathrm{ug} / \mathrm{L}$ ethidium bromide 
included. Gels for preliminary screening were $12 \mathrm{~cm} \times 10 \mathrm{~cm} \times 0.8$ $\mathrm{cm}$ and were run at approximately 25 volts for 18 hours at constant current. To enhance the resolution of the fragments for quantification, longer gels $(19 \mathrm{~cm} \times 15 \mathrm{~cm} \times 1 \mathrm{~cm})$ were used and run at 20 to 25 volts for 40 to 50 hours. Gels were run immersed in $1 x$ TAE buffer with $250 \mathrm{ug} / \mathrm{l}$ ethidium bromide included. One microgram of lambda DNA cut with either Hind III or Hind III and Pst I was used as the size marker. Three identical standards were run on each gel in order to assess the variability in the fragment mobilities. For one gel (the gel containing the Pst I, Hind III and Bam HI digests) the standard deviations of the means of each triplicate set of Hind III/lambda DNA fragments range from .06 to $0.18 \mathrm{~cm}$. Since the DNA fragments separate in a nonlinear fashion (mobility of restriction fragment is a logarithmic function of its size) the error bars on these mobility data correspond to a range of fragment length differences and depends on the region of the gel considered. Choosing the higher of the two values to be conservative, a standard deviation of tor- $0.18 \mathrm{~cm}$ is used throughout the range of fragment mobilities. The resulting deviation in fragment sizes (in kilobase pairs) increases considerably at the larger end of the spectrum (see figure 1). When comparing diatom DNA fragment lengths on a particular gel, this variability was accounted for and if the mobility differences of a set of cPDNA fragments being compared on adjacent lanes fell within this range of variability they were considered to be equal in size. 
Southern Blot Transfer of DNA to Nytran 8 Membrane

After photographing the gel on a UV transilluminator with Polaroid type 667. film, the DNA in the gels was denatured in $0.5 \mathrm{M}$ $\mathrm{NaOH}, 1.5 \mathrm{M} \mathrm{NaCl}$ for 30 minutes at room temperature followed by a deionized water rinse and neutralization in $0.5 \mathrm{M}$ tris $\mathrm{pH} 7.0,1.5 \mathrm{M}$ $\mathrm{NaCl}$ for an additional 30 minutes, also at room temperature. DNA was transfered from the agarose gel to the surface of a piece of Nytran $\circledast$ membrane (Scheicher and Schuell, Keene, N.H.) according to the original method of Southern (Southern 1975) replacing nitrocellulose membrane with nylon Nytran $\circledast$ membrane and using $10 \times$ SSC (1.5 M NaCl, $150 \mathrm{mM} \mathrm{Na}$ citrate $\mathrm{pH} \mathrm{7.0)}$ as the transfer buffer. After an overnight transfer, the Nytran ${ }^{8}$ membrane was washed briefly in $2 X \mathrm{XSC}$ and baked at $80^{\circ} \mathrm{C}$ for 1.5 hours. At this point the membrane was considered ready for prehybridization treatment.

\section{Preparation of the gene probe}

The two Chlamydomonas reinhardtii cpDNA probes used in this study were kindly provided by N. Gillham, E. Harris, and J. Boynton, Duke University. The $23 S$ rDNA gene is a $4.1 \mathrm{~kb}$ gene fragment cloned into puC 8 plasmid at the Bam HI/Eco RI sites and amplified in the E coli clone P177. The rbc $L$ gene is a $5.8 \mathrm{~kb}$ gene fragment, also cloned into puC 8 plasmid at the Eco RI site and amplified in E. coli clone p67b. Plasmid purification was according to the method outlined in Maniatis et al (Maniatis et al. 1983) for amplification in rich medium using ampicillin. Plasmid DNA was separated from 
bacterial genomic DNA by centrifugation in cesium chloride ethidium bromide gradients $(1.55 \mathrm{~g} / \mathrm{ml}, 18-24$ hours at $40,000 \mathrm{rpm}$ in Beckman $80 \mathrm{Ti}$ rotor). The plasmid bands were removed and purified as described previously for diatom DNA. The $\underline{c}$ reinhardtii gene probe inserts were separated from the pUC 8 plasmid vector by digesting with the appropriate restriction enzymes and separating the resulting fragments on neutral $0.8 \%$ preparative agarose gels. The appropriate band was then physically cut from the gel and the DNA was electroeluted into a dialysis bag as described by Maniatis et al (1983) using $1 \times$ TAE buffer (40mM tris-acetate $1 \mathrm{mM}$ EDTA) instead if 0.5X TBE. The DNA was ethanol precipitated as previously described and reconstituted in TE such that the final DNA concentration was approximately $50 \mathrm{ng} / \mathrm{ul}$. No attempt was made to remove bound ethidium bromide as it did not seem to interfere with subsequent labeling or hybridization reactions.

\section{Oligolabeling of probe DNA with 32 P-ATP}

Probes were radioactively labeled with $32 \mathrm{P}$-ATP using a variation of the oligolabeling procedure of Feinberg and Vogelstein (Feinberg and Vogelstein 1983) as communicated by Steve Dellaporta (Cold Spring Harbor Laboratory, New York) as follows: In a $1.5 \mathrm{ml}$ microfuge tube, 2 to 3 ul of probe DNA solution (50 to $150 \mathrm{ng}$ ), 1 ul of $1 \mathrm{ug} / \mathrm{ul} \mathrm{pdN} 6$ (mixture of random oligodeoxynucleotide hexamers, Pharmacia) and appropriate amount of deionized water were added such that final reaction volume is $30 \mathrm{ul}$. This mixture was immersed in a boiling water bath for five minutes, centrifuged for five to ten seconds and then to this was added 3 ul of 10X OLB II 
(100 mM MgCl $2,50 \%$ glycerol, $0.2 \mathrm{mM}$ dTTP, $0.2 \mathrm{mM}$ dGTP, $0.2 \mathrm{mM}$ dCTP, $100 \mathrm{mM}$ beta-mercaptoethanol, $386 \mathrm{mM}$ tris, pH 7.5), 3 ul of alpha-32 P-ATP (50 uCi deoxyadenine-5'-triphosphate, (alpha-32P) tetratriethylammonium salt, $3000 \mathrm{Ci} / \mathrm{mmole}$ specific activity, (ICN biomedicals)) and 1 to 3 units of Klenow fragment of DNA polymerase 1 (Pharmacia). The reaction proceeded at room temperature for two hours to overnight, and was terminated by the addition of $80 \mathrm{ul}$ of stop buffer $(20 \mathrm{mM} \mathrm{NaCl}, 20 \mathrm{mM}$ tris- $\mathrm{HCl} \mathrm{pH} 7.5$, $2 \mathrm{mM}$ EDTA, $0.25 \% \mathrm{SDS}$ ). The labeled probe was purified from unreacted 32 p-ATP by passing the reaction mixture through a $1 \mathrm{ml}$ column of Sepharose CL6B 200 in TE, in a clinical centrifuge. The labeling reaction was considered successful if at least twenty percent of the radioactivity was found in the column eluent. This is equal to a specific activity of $4.4 \times 10^{8} \mathrm{dpm} / \mathrm{ug}$ of probe DNA. Then, $500 \mathrm{ul}$ of deionized water and $100 \mathrm{ul}$ of $10 \mathrm{mg} / \mathrm{ml}$ salmon sperm DNA was added to the column eluent and denatured in a boiling water bath for five minutes. This solution was added directly to the hybridization bag.

\section{Eilter hybridization}

Filter hybridization methods are as communicated by Jychian Chen (Cold Spring Harbor Laboratory, New York). Nytran® filters were prehybridized in $1 \mathrm{X}$ hybridization solution ( $11.1 \mathrm{X} \mathrm{SCP}, 185$ $\mathrm{mg} / \mathrm{L}$ dextran sulfate, $1.85 \% \mathrm{~N}$-lauryl-sarcosine, and $1.0 \mathrm{mg} / \mathrm{ml}$ heparin; stored unfiltered at $-20^{\circ} \mathrm{C}$ as a $2 \mathrm{X}$ concentrate) at $65^{\circ} \mathrm{C}$ for at least one hour prior to addition of probe solution. Hybridization was at $65^{\circ} \mathrm{C}$ overnight in a shaking bath. Filters were prehybridized 
and hybridized in Kopak Scotchpak ${ }^{\circledR}$ sealable pouches (Kopak, Minneapolis, MN.). At the conclusion of the hybridization period, filters were washed two times at fifteen minutes each in $1 X$ wash (2X SSC, 1\% SDS) and two times for 15 minutes each in $0.1 \mathrm{X}$ wash ( $0.2 \times$ SSC, $0.1 \% S D S$ ) at the hybridization temperature. The filters were blotted dry, wrapped in plastic wrap and exposed for six hours to several days at $-80^{\circ} \mathrm{C}$ using one or two intensifying screens and Kodak X-Omat AR 5 film. To reprobe, the filters were washed for thirty minutes at room temperature in $0.4 \mathrm{M} \mathrm{NaOH}$, rinsed with deionized water and neutralized thirty minutes in $1 \mathrm{M}$ tris $\mathrm{pH} 8.0$.

\section{DNA Quantification by Fluorescence}

DNA concentration was also quantified directly by fluorescence using a Hoefer model TKO 100 Fluorometer and the DNA binding dye Hoechst 33258. DNA samples were diluted in filtered $1 X$ TNE buffer (10X TNE $=100 \mathrm{mM}$ tris, $10 \mathrm{mM}$ EDTA, $1.0 \mathrm{M} \mathrm{NaCl}, \mathrm{pH}$ 7.4). The instrument was manually zeroed against $2 \mathrm{ml}$ of $1 X$ TNE buffer with $0.1 \mathrm{ug} / \mathrm{ml}$ Hoechst dye 33258 in a one centimeter cuvette. The instrument was standardized versus a single calf thymus DNA sample of final concentration in cuvette of $250 \mathrm{ng} / \mathrm{ml}$. All subsequent DNA samples were diluted to a final concentration close to $250 \mathrm{ng} / \mathrm{ml}$ and read directly from the instrument. Samples were done in duplicate and standards were run several times to correct for instrument drift. 


\section{Protein Determination}

Protein concentrations were determined on all DNA samples using the Bio-Rad Protein Microassay procedure, a modification of the Bradford method (Bradford 1976). DNA samples are diluted up to

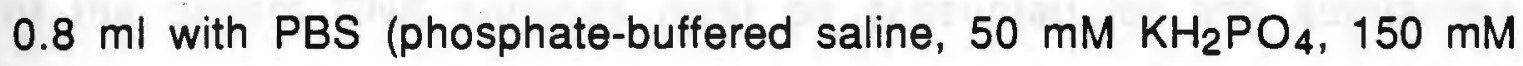
$\mathrm{NaCl}, \mathrm{pH} 7.2)$ and $0.2 \mathrm{ml}$ of undiluted dye reagent was added, mixed, and allowed to set for five minutes to one hour prior to reading absorbance at $595 \mathrm{~nm}$ in a one centimeter cuvette. $O D$ values were compared versus a BSA standard curve to calculate protein concentration (as BSA equivalent). Instrument was zeroed versus a reagent blank composed of $0.8 \mathrm{ml}$ PBS and $0.2 \mathrm{ml}$ concentrated dye reagent. Values were corrected for instrument drift by frequent measurements of this blank.

\section{Polysaccharide Determination}

Polysaccharide content was determined by the phenol, sulfuric acid method of Dubois et al (Dubois et al. 1956) using glucose-D as the standard. Concentrated DNA or glucose samples were diluted to a final volume of two milliliters in deionized water into a fifteen milliliter polystyrene centrifuge tube. Fifty microliters of eighty percent phenol and five milliliters of concentrated sulphuric acid were added in quick succession. This solution was allowed to react for ten minutes and then shaken and placed into a thirty degree (celsius) water bath for twenty minutes. A blank sample omitting the glucose or DNA was run with each batch and the instrument was zeroed to this sample periodically. Readings were done in a one 
centimeter quartz cuvette at 490 nanometers using a slit width of 0.1 nanometers.

Because nucleic acid is a ribose polymer and is therefore detected by this polysaccharide assay, the nucleic acid components of the diatom DNA samples must be accounted for and subtracted from any estimate of hexose polysaccharide detected in the sample by this assay. Pure salmon sperm DNA samples were assayed at increasing concentrations bracketing the samples and a standard curve was drawn. From this standard curve, the absorbance at 490 nanometers of a given amount of DNA was known. The absorbance value for the microgram amount of diatom DNA used in the original samples (known from previous fluorescence measurements) was estimated from this standard curve. This absorbance value was subtracted from the absorbance value obtained from assaying the diatom DNA directly. The resulting value reflected the amount of polysaccharide (and RNA) in glucose equivalents, present in the sample.

\section{Results}

Table 2 lists the 15 DNA preps done on multiple clones of I. nordenskioeldii, I gravida, and I rotula with some data from the significant steps in each prep. Although some of the purification steps and measurements were not done for some of the preps (dashed line in Table 2) there are ample data available to make some comparisons between and within preps. For example, centrifuging the french press lysate (purification step 1) resulted in 
significantly less precipitated nucleic acid $\left(A_{260}\right.$ units in purification step 5) in preps 1,4 and 6 when compared to preps 9,10 and 13 where the centrifugation step was omitted. This is likely due to the large amount of cytoplasmic RNA which is not pelleted. The $A_{260} / A_{280}$ ratios in purification step 3 indicate relatively high amounts of protein in preps one and four which were eliminated in the subsequent digestions with proteinase $K$ (purification step \#4, table 2). The high $A_{260} / A_{280}$ ratios (2.0 to 2.15 in purification step six) indicate a preponderance of RNA or other contaminating substances in those samples. The DNA is separated from other nucleic acid and protein contaminants by banding in a cesium chloride - ethidium bromide isopycnic ultracentrifugation step (purification step seven) which decreased the $A_{260} / A_{280}$ ratio to approximately 1.8 in all but the I rotula samples (purification steps nine and twelve). After repeated purification attempts by additional $\mathrm{CsCl}$ gradients, proteinase $\mathrm{K}$ and RNase $\mathrm{A}$ digestions and phenol extractions (not included in Table 2) the I rotula nucleic acid sample's $A_{260} / A_{280}$ ratios remained at approximately 2.0. These DNA samples digested less consistently well than did the DNA with $A_{260} / A_{280}$ ratios closer to 1.8 (I gravida and I nerdenskioeldii) and exhibited less apparent homology to heterologous cpDNA cloned

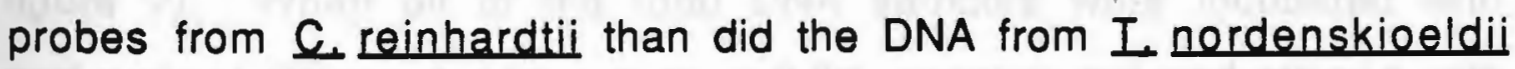
and I gravida.

The total DNA samples from the eight diatom clones studied were assayed for their DNA, RNA, protein and polysaccharide content in order to determine a chemical dissimilarity with the I rotula 
DNA (Table 3). DNA concentrations, determined by absorbance at 260 $\mathrm{nm}$, were always greater for the I rotula DNA when compared to the concentrations as determined by Hoechst dye fluorescence. Conversely, with the two clones of $I$ gravida and one of $I$ nordenskioeldii, the OD 260 method DNA estimates were lower than the DNA estimates as determined by fluorescence. Protein concentrations were not significantly higher in the I rotula samples than in the others and this is also indicated by the fact that all the DNA solutions A260/A280 ratios were greater than 1.8 .

Polysaccharide, as glucose equivalents, was detectable in all the diatom DNA assayed. When measured as microgram equivalents of glucose-D per microgram of DNA (determined fluorometrically) it was found in five to ten fold higher ratios in three clones of $I$. rotula DNA and in one clone of I nordenskioeldii DNA (clone HB3). Although all the polysaccharide measurements were corrected for the known DNA content (nucleic acid is a ribose-polymer therefore detected by the assay) they were not corrected for RNA content. When a qualitative RNA assay was done only the one $I$. nordenskioeldii clone (HB3) which showed high "polysaccharide" amounts had significant RNA contamination ( $50 \%$, judged visually, figure 2). When all of the total DNA samples were incubated with and without RNase $A$ and run on a $0.8 \%$ agarose gel and stained with ethidium bromide, only HB3 (lane 1) total DNA had detectable RNase - labile material, suggesting that its high "polysaccharide"/DNA ratio may be due to a preponderance of RNA and not true storage or structural polysaccharide. It is likely, then, that the DNA extracted 
and purified from the three clones of I rotula had considerably more polysaccharide contaminant than any of the DNA isolated from either I nordenskioeldii or I gravida. That polysaccharide material should still contaminate DNA samples purified through multiple $\mathrm{CsCl}$ gradients is not unusual. Removal of polysaccharides from DNA preparations by $\mathrm{CsCl}$ gradients has proven ineffectual in other studies because of their similar buoyant densities (Edelman 1975; Edelman et al. 1967).

UV spectral analysis of all the DNA samples from the three species of Thalassiosira also suggests a physical or chemical dissimilarity in the DNA isolated from I rotula (figure 3). All the DNA samples, including purified salmon sperm DNA used as a standard, exhibited two absorbance peaks, one at approximately 260 $\mathrm{nm}$ and another at 213 to $224 \mathrm{~nm}$. The $260 \mathrm{~nm}$ peak, the absorbance maximum for nucleic acid, broadens and flattens in the UV spectra for the two clones of I rotula while this peak in all other DNA spectra is sharp. The identity of the substance responsible for the second absorbance peak is not known, but is found in all the DNA samples including the lambda DNA standard and is therefore not considered anomolous.

$\mathrm{CsCl}$ isopycnic ultracentrifugation using the DNA binding dye Hoechst 33258 (Aldrich and Cattolico 1981; Aldrich et al. 1982; Goff and Coleman 1988) repeatedly separated I rotula clones F4 and TR4 total DNA into three distinct fluorescing bands yet failed to do so in all other clones of diatoms including one other clone of I rotula (clone T3). Figure 4 is a diagrammatic representation of the results 
from centrifuging to equilibrium in $\mathrm{CsCl}$ - Hoechst dye gradients the total DNA from seven of the diatom clones of the three species studied. The bands indicate the approximate positions and sizes of the Hoechst fluorescing bands when viewed under ultra-violet light. The dark bands indicate bands of high intensity with sharp upper and lower borders while the stippled bands indicate bands of lesser intensity with less well-defined upper and lower borders. I rotula clones F4 and TR4 exhibited similar patterns of DNA separation in these gradients with upper and lower bands appearing in similar relative positions. The middle band in TR4, however, is much smaller than the corresponding middle band in F4. When band F4-1 is removed and re-centrifuged in a gradient identical to the first, a band appears in exactly the same position as before for F4-1. Diffuse fluorescing DNA below this sharp band indicates contaminating DNA, probably from band F4-2 which may have been inadvertently removed along with F4-1. Total DNA from I rotula clone T3 exhibited a pattern with a single upper diffuse band and a lower sharper band. Total DNA from I nordenskioeldii clones HB3 and $X 1$ and $\mathrm{L}$ gravida clone TTG2 exhibited double broad diffuse bands with no sharp bands appearing at all. The I gravida clone TTG4 DNA, however, exhibited a single lower broad diffuse band and two upper sharp, well-defined bands which were so closely spaced, they had to be removed as one band, band TTG4-1. All the CsClHoechst dye gradients were run identically, the only difference being the quality of the total DNA loaded onto them. The three gradients which produced broad diffuse bands, HB3, X1 and TTG2 were loaded with total DNA which had been initially purified in a CsCl-ethidium 
bromide gradient. All other DNA loaded onto $\mathrm{CsCl}$-Hoechst dye gradients had not been initially purified with a $\mathrm{CsCl}$-ethidium bromide gradient (See table 2).

The DNA from the three $\mathrm{CsCl}$-Hoechst dye gradient bands from I rotula clone F4 DNA (bands F4-1, F4-2, and F4-3, figure 4) along with total DNA before the $\mathrm{CsCl}$-Hoechst gradient, when probed with the heterologous cloned probe of the cpDNA rbcL gene from $C$. reinhardtii, hybridized to this cpDNA probe to different degrees (figure 5). The top band, F4-1, shows the strongest signal to this cpDNA probe when compared to an approximate equal amount of total F4 DNA loaded onto the gel ( $5 \mathrm{ug}$ ). F4-2 and F4-3 DNA from the middle and lowest bands in the $\mathrm{CsCl}-\mathrm{Hoechst}$ dye gradient, exhibited a much lower signal to this probe indicating much smaller amounts of this rbcL gene-positive DNA present, or more simply, much less cpDNA present. The small amounts of rbcL probe-positive DNA present in F4-2 and F4-3 probably represents cross contamination occurring in the $\mathrm{CsCl}$-Hoechst gradient. The origin or identity of the F4-2 and F4-3 DNA is not known, but may represent DNA from the nucleus or mitochondria of the diatom cell, DNA from contaminating bacteria or circular cPDNA which has been linearized. The F4-1/Hind III fragments to which the rbc $L$ probe hybridized are 8.2, 7.4, 5.3, 3.3, 2.8, and 1.9 kilobase pairs in length. All these fragments with the exception of two, the 8.2 and the $2.8 \mathrm{~kb}$ fragments, appear as bright ethidium bromide bands in the F4-1 agarose gel lane. The two exceptions appear as very faint bands (see figure 5). 
That the upper band in the $\mathrm{CsCl}-\mathrm{Hoechst}$ dye gradient contains the CPDNA fraction is consistent with the binding properties of Hoechst 33258 . This dye preferentially binds to A-T rich regions of double-stranded DNA (Manuelidis 1977). cpDNA, containing a high proportion of A-T regions (Palmer 1987) binds Hoechst dye to a greater extent then mitochondrial or nuclear DNA. The intercalation of this dye within the rigid circular double helix structure of $c p D N A$ causes some unwinding and results in a greater buoyancy in $\mathrm{CsCl}$ gradients. cpDNA from kelp (Fain et al. 1988), Olisthodiscus luteus (Aldrich and Cattolico 1981; Aldrich et al. 1982) and some red alga species (Goff and Coleman 1988) also are isolated from total cellular DNA as the uppermost fraction on CsCl-Hoechst 33258 isopycnic gradients.

\section{Estimates of chloroplast genome size for $I$ rotula.}

To estimate the chloroplast genome size for I rotula, clone $\mathrm{F} 4$, the purified DNA from the upper portion of the $\mathrm{CsCl}$ Hoechst dye gradient (band F4-1) was digested with the restriction enzyme Pst 1 and the fragments separated on a $0.8 \%$ agarose gel. The sum of the lengths of the resulting 18 fragments is 146.9 kilobase pairs when compared against a lambda DNA standard digested with Hind III (see figure 6). Although it is possible that some of the counted fragments represent incomplete digests, a long incubation time and high enzyme concentration minimized this possibility. No attempt was made to determine the stoichiometery of the fragments; all fragments were given equal weight. 


\section{Estimates of Total DNA content per Cell}

For those DNA preps where total DNA is isolated from preparations of total cellular nucleic acid and for which cell counts were done, it is possible to estimate total DNA on a per cell basis (see table 3). Total DNA was purified by $\mathrm{CsCl}$-ethidium bromide isopycnic ultracentrifugation and quantified by absorption at $260 \mathrm{~nm}$ assuming that an optical density of 1.0 in a one centimeter cuvette equals a DNA concentration of $50 \mathrm{ug} / \mathrm{ml}$. Amounts of DNA per cell for I gravida, I rotula and I nordenskioeldii ranged from 0.28 to 1.4 picograms. Precision within a species was good as two clones of Inordenskioeldii, HB3 and X1 exhibited a cellular DNA content of $0.35 \mathrm{pg}$ and $0.28 \mathrm{pg}$, respectively. Cellular DNA content for I rotula clone TR4 was higher at $0.65 \mathrm{pg} /$ cell but this is tempered by the fact that the spectrophotometeric DNA determination may be overestimated as evidenced by the high $A_{260} / A_{280}$ ratio (2.04). The I gravida clone TTG2 showed considerably higher DNA content per cell - about four times that for the two clones of I nerdenskioeldii.

\section{Bacterial DNA Contamination}

Due to the ever-present epiphytic bacteria in the diatom cultures and the great difficulty in eliminating them, especially through repeated transfers from ten milliliter cultures up to twenty liter cultures outside of a sterile hood, it was necessary to estimate what proportion of the total DNA isolated was actually derived from these bacterial contaminants. It was estimated by epifluorescence counts that approximately forty percent of the 
bacterial cells present in the final twenty-liter culture were poured off in the supernatant after the first centrifugation step and, thus, were eliminated. Epifluorescent counts of an aliquot of a wellmixed twenty-liter culture before centrifugation showed roughly 7.0 $\times 10^{9}$ bacteria cells total ( $I$ nordenskioeldii, prep \#8, table 2). Then, sixty-percent of this number, or $4.2 \times 10^{9}$ bacterial cells were estimated present in this diatom pellet. Various estimates of DNA content of mixed natural assemblages of marine bacteria range from 2.5 to $9.8 \mathrm{fg}$ DNA per cell (Bak et al. 1970; Bell 1986; Chin-Leo and and Kirchman 1990; Fuhrman and Azam 1982; McCoy and Olson 1985; Paul and and Jeffrey 1985; Paul and Carlson 1984). Using these estimates, an approximation of the bacterial cell DNA present in the total "diatom" DNA preparation is 10.5 to 41.0 micrograms. Of the 810 micrograms of total DNA recovered from the $\mathrm{CsCl}$-ethidium bromide gradient for I nordenskioeldii (prep \#8, table 2) this would represent 1.3 to 5.1 percent bacterial DNA contamination. These, however, are probably overestimates due to the lack of data to estimate the loss of bacterial and diatom DNA through the purification steps. Undoubtedly bacterial DNA would be affected in similar physical and chemical ways to diatom DNA in terms of shearing forces, solubility, precipitation and buoyancy in $\mathrm{CsCl}$ ethidium bromide gradients.

\section{Restriction Enzyme Analysis}

Due to the lack of sufficient amounts of purified diatom chloroplast DNA, the extreme difficulty of the purification methods and the apparent serendipitous nature of the successes, the total 
cellular DNA fraction (after $\mathrm{CsCl}$ - ethidium bromide isopycnic ultracentrifugation step) was used for the restriction digests and subsequent fragment length comparisons. Twelve restriction enzymes (six base cutters) were used to digest the total DNA from the eight clones of Thalassiosira. All DNA preparations except those from I rotula, consistently exhibited complete digestion. The DNA from the three I rotula clones, however, digested only partially or not at all. For the I. nordenskioeldii and I gravida samples, the highly repetitive regions of the total DNA appeared as distinct bands within a background haze of fluorescence. The fragment patterns appeared to be conserved within a given species. These DNA fragments could have originated from the genome of the mitochondria, the chloroplast or highly repetitive regions of the nuclear genome. The background fluorescence was likely due to fragments of single copy regions of the same DNA separating on the agarose gel as a continuous smear, the gel unable to resolve DNA fragments differing so little in length. This same background "smear" was also present in electrophoresed, undigested total DNA (see figure 2) and probably represents physically sheared or chemically degraded low molecular weight DNA. It is observed also that most of the cpDNA hybridization signals on the nylon membranes to which the DNA was transfered, roughly correspond to the highly fluorescent, distinct bands. Absolute measurement of band position is impossible, though, due to the deformation of the large, flimsy agarose gel during DNA transfer to nylon membrane. 


\section{Hybridization Data}

Figures 7 and 8 show the autoradiographs resulting from hybridizations of two chloroplast DNA gene probes from Chlamydomonas reinhardtii to the restriction enzyme digests of the eight clones of two species within the genus Ihalassiosira. The gene probes, P177 (23S rDNA gene) and P67b (rbc L gene) hybridized consistently well to the total DNA digests from I nordenskioeldii and I gravida under high stringency conditions but not at all to the total DNA of I rotula under similar conditions. Hybridization to I rotula DNA occurred only when the stringency was lowered. Data from these hybridizations, however, would not be suitable for comparison to the RFLP data of I gravida and I nordenskioeldii due to the changed reaction conditions. Subsequently, there are no hybridizations for I rotula to compare to the fragment patterns with either of the other two species. The data available will allow only comparisons within and between the three clones of I nordenskieoldii and the two clones of I gravida. Hybridization conditions were stringent, $\left(65\right.$ to $\left.70^{\circ} \mathrm{C}\right)$ to eliminate or at least minimize the least specific hybridizations to non chloroplast DNA sequences (i.e., nuclear and mitochondrial diatom and bacterial DNA). When hybridization conditions were lowered below approximately $60^{\circ} \mathrm{C}$, hybridization to the lambda DNA standard sometimes occurred, although, neither probe hybridized to the I rotula DNA (data not shown). 
Of the twelve restriction enzymes used in this study only ten provided DNA digests of sufficient quality for successful hybridizations. Digestions using the restriction enzymes Bam $\mathrm{HI}$ and Sac I resulted in a smeared hybridization signal with no distinct bands. A tabulation of the number of and size of the restriction fragments which hybridized to the two cpDNA probes is found in table 4. In all, forty-four restriction fragments of diatom DNA ranging in size from 0.9 to 23.0 kilobase pairs were detected by the C. reinhardtii cpDNA probes. Since each enzyme recognizes a sixbase sequence, then each fragment represents six bases recognized by a restriction enzyme, and a total of 264 chloroplast DNA bases were detected by all the restriction enzymes. Using the estimated chloroplast genome size of 147 kilobase pairs, this equals $0.18 \%$ of the genome analyzed:

(44 fragments $\times 6$ bases per fragment per genome / 147,000 bases per genome $=0.0018$ )

Only those cpDNA fragments containing the homologous sequences to the $\underline{C}$ reinhardtii probes are detected when hybridization is to total DNA digests, as in this analysis. All other CPDNA sequences remain obscured by the high background of nuclear DNA digests. As a result, it is impossible to make conclusions about locations of point and length mutations and about their absolute frequency within these genomes studied. Table 4 lists those, presumably chloroplast, DNA fragments which contain the sequences homologous to the rbc $L$ and $23 S$ rDNA genes of $\underline{c}$ reinhardtii cPDNA. As these gene sequences are known to be highly conserved 
through phylogenetic lines (Palmer 1985a; Palmer 1987) and because high stringency hybridization conditions were employed, it is assumed that those fragments contain, in whole or in part, those same gene sequences in diatom cpDNA.

The rbc $L$ probe and the $23 S$ rDNA probe rarely hybridized to the same fragment (Table 4), with the exception that these two gene sequences are identified to the same $17.5 \mathrm{~kb}$ Eco RV and $1.5 \mathrm{~kb}$ Dra I fragments in the three clones of I nordenskioeldii (Table 5). More fragments were detected by the $23 S$ rDNA probe than the rbc $L$ probe (27 versus 19). This may be due to the higher concentration of the ribosomal DNA genes in cpDNA due to their typical occurrence on the inverted repeat region of the genome and the $r b c L$ gene typically being a single copy gene (Palmer 1985a; Palmer 1987).

The fragment patterns detected by the two gene probes were identical for the three clones of I nordenskioeldii for all ten restriction digests (Figures: 8-12, Table: 5). There are limited data for clone HB3 due to lack of hybridization of probes to many of these digests, probably due to small amounts of DNA loaded onto these gels. But for the data available, the two clones isolated from Hull Bay, Massachusetts, one year apart (clones HB3 and ZUD2) and the one clone isolated from Narragansett Bay (clone X1) show identical banding patterns. The two clones of $I$ gravida used in this study (clones TTG2 and TTG4), both isolated at the same time from Tromso, Norway but separated from one another in culture for more than ten years, also exhibit banding patterns identical to one another with the one exception of the Eco RI - 23S rDNA fragments 
differing in size by 0.6 kilobases. In none of the I gravida DNA digests were the two probe gene sequences located on the same fragment, in contrast to the two In nordenskioeldii fragments already mentioned. These results seemed to be highly reproducible for at least six of the enzymes and the P177 (23S rDNA) gene probe. The fragments identified on the replicate gels (numbers in parenthesis, table 5) corresponded to one another very well, the calculated sizes differing, in most cases, by only a few kilobase pairs.

Data from table 5 can be used to build similarity matrices to quantify the size differences of those fragments detected by the two $\mathrm{C}$ reinhardtii cPDNA probes. Those data for each probe in table 5 which comprise the most complete data set are used (numbers in bold type). Because of the paucity of data for I nordenskioeldii clone HB3, these data are omitted from the similarity matrix. Table 6 shows three matrices, one each for the two genes considered separately, and one considering both genes together. The equation used to calculate similarity is from $\mathrm{Nei}$ and $\mathrm{Li}$ ( $\mathrm{Nei}$ and $\mathrm{Li} \mathrm{1979):}$

$$
S=2 N_{x y} / N_{x}+N_{y}
$$

where $S=$ the proportion of share restriction fragments, $N_{x y}=$ the number of shared restriction fragments in the sets $x$ and $y$, and $N_{x}$ and $N_{y}=$ the total number of restriction fragments considered for sets $x$ and $y$ respectively. When the total data set is considered (upper matrix, table 6) there is nearly absolute similarity of fragment pattern within a species for I gravida and I 
nordenskioeldii. All fragments are identical between the two clones of $\mathrm{L}$ nerdenskioeldii, therefore the similarity index is 1.0. The two I gravida clones, on the other hand, show more heterogeneity due to the two Eco RI - P177 fragment differences (table 5), and has a similarity index of 0.91 . Between the two species, however, only 0.32 of the detected cPDNA fragments are shared. Since similar fragment patterns means similar relative position of restriction sites, then the two species $I$ nordenskioeldii and $I$ gravida, are identical in thirty-two percent of the cpDNA nucleotides surveyed.

When considered on an individual basis, the similarity of restriction fragments size between species is greater for the $23 \mathrm{~S}$ rDNA fragments than for the rbcL fragments (0.38 vs. 0.15). The calculations for the $r b c L$ gene fragments are, however, based on a relatively small data set.

\section{Discussion}

Due to some chemical dissimilarity of the I rotula DNA solution to the DNA solutions of both $I$ nordenskioeldii and I gravida, a comparison of the restriction fragment length polymorphisms between I rotula and I gravida could not be made. The chemical dissimilarity possibly prevented restriction enzyme digestion (figure 7) and/or hybridization to the two heterologous $\underline{C}$ reinhardtii cpDNA probes under stringent hybridization conditions. Sometimes when conditions were made less stringent (hybridization temp. $<57^{\circ}$ C) the probes would hybridize to I rotula DNA as shown in figure 5, though inconsistently from gel to gel. The value of these 
hybridization data, however, is lessened at low stringency, due to the greater likelihood of the probe binding to less homologous DNA sequences. When the hybridization temperature was lowered to $57^{\circ} \mathrm{C}$ or below, from the customary 65 to $70^{\circ} \mathrm{C}$, the cpDNA probes hybridized weakly to I rotula DNA but also strongly to the lambda DNA standard (data not shown). It was necessary, however, to keep the hybridization conditions as stringent as possible to prevent probe hybridization to non-homologous sequences in the DNA of both the diatoms and the contaminating bacteria. Sometimes it was necessary to increase the wash temperature to near $80^{\circ} \mathrm{C}$ to diminish the strong signal to I gravida and I nordenskioeldii DNA to the point where individual bands could be distinguished. It is assumed, then, that due to the high stringency conditions employed, the hybridizations which occurred were to the most homologous sequences available in the diatom DNA, namely, the cPDNA sequences, but the use of such extreme conditions possibly precluded hybridization to I rotula DNA.

There are a number of possible reasons why the $\underline{c}$ reinhardtii cpDNA probes did not hybridize sufficiently well to I rotula DNA as compared to the other diatom DNA, or why it sometimes resisted digestion with restriction enzymes. The most compelling reason is the quality of the DNA. The high amounts of polysaccharides found in the preparations of I rotula DNA along with its anomalous UV spectra and UV absorbance for quantification, suggest that there may have been some kind of chemical interference responsible. Polysaccharide contamination of DNA preparations is not unusual in 
algae (Edelman 1975; Edelman et al. 1967; Murray and Thompson 1980 ) and has been reported to affect DNA-DNA reassociation kinetics in plant studies (Murray and Thompson 1976). Edelman et al. (1967) found polysaccharides (from the blue-green algae, order escillatoriales) to consistently contaminate their DNA preparations, even following repeated preparative $\mathrm{CsCl}$ gradients, phenol extractions and ethanol precipitations (Edelman et al. 1967). The suspected polysaccharides all had buoyant densities in $\mathrm{CsCl}$ similar to that of DNA (DNA:1.75-1.68 $\mathrm{g} / \mathrm{cm}^{3}$; polysac: $1.75-1.65$ $\mathrm{g} / \mathrm{cm}^{3}$ ) therefore they comigrated with the DNA through the $\mathrm{CsCl}$ gradient steps (Edelman 1975). Ethanol precipitation of the DNA may have also precipitated the polysaccharides as this is a customary procedure for isolating polysaccharides from algae (Beattie et al. 1961). Also, although this possibility was not tested for the $I$ rotula DNA, it is possible that the anomalous UV spectra could be a result of light scattering by polysaccharide in the UV region, as was reported by Edelman et al (1967) for the Oscillatoriales' DNA. The consistantly high DNA concentration values obtained for I rotula DNA by UV absorbance analysis (table 3 ) also indicate light scattering by polysaccharides was occurring in these samples. In the dual beam spectrophotometer used, the collection angle of the photomultiplier tube is too shallow to collect the forward scattered light which occurs in Rayleigh scattering (molecular scattering). This scattered light, not transmitted to and counted by the photocollector, is "assumed" by the instrument to be absorbed, and is included in the optical density value (Kirk 1983). 
The high relative amounts of polysaccharide to DNA in the I rotula DNA preparations $(5.5: 1$ to $31.5: 1$; table 3$)$ suggest that this contaminant could upset conditions for restriction reactions or hybridizations. Consider that a restriction digestion reaction containing five micrograms of TR4. DNA with a polysaccharide to DNA ratio of 31.5 (see table 3), will contain 157.5 micrograms of polysaccharide. This level of contamination could easily effect the balance of $\mathrm{pH}$ and ionic strength important for optimal restriction and hybridization reactions (Brooks 1987; Wahl et al. 1987).

Other possible contaminants which would have inhibited restriction and hybridization of I rotula DNA are $\mathrm{CsCl}$ salts and phenol. Although phenol is a known inhibitor of restriction endonucleases (Brooks 1987; Maniatis et al. 1983), it is unlikely that it was a problem here since several purification steps followed the phenol-chloroform extractions and would have rid the DNA of any trace of phenol. Cesium chloride contamination is an outside possibility, however. Several times following the cesium chloride step when the fluorescing DNA band, removed from the $\mathrm{CsCl}$ gradient, was precipitated with ethanol, crystalline salts also precipitated. These were assumed to be $\mathrm{CsCl}$ salts. This problem was remedied, however, by diluting the $\mathrm{DNA} / \mathrm{CsCl}$ mixture many-fold with water before precipitating with ethanol.

Another possible reason for the I rotula DNA resistance to restriction digestion is the presence of methylated bases within the recognition sites for those enzymes. Modification of recognition 
site bases by methylation prevents restriction at that site by a particular enzyme (Raleigh 1987). There are two reasons, however, why this is not a viable reason for the lack of consistent restriction of I rotula DNA. Firstly, although plant nuclear DNA has consistently been found to contain methylated bases, to date, no cPDNA has been found to be methylated (Palmer 1986). Assuming that the I rotula DNA does indeed contain a substantial fraction of cpDNA, then that fraction would not be resistant to digestion with methylation-sensitive restriction enzymes and should produce digestion products on the agarose gel. Secondly, and more convincingly, the lack of restriction of I retula DNA was an inconsistent problem, precluding the possibility of the DNA possessing a permanent physical resistance to restriction, such as methylation. The inconsistent problems with digestion, then, probably stem from the high amounts of polysaccharides contaminating the DNA, and the variable degrees to which it was dissolved. It was occasionally noticed when pipetting these DNA preparations that there were substantial amounts of precipitated gel-like substances present. These could be precipitates of polysaccharides which, due to temperature and concentration effects, moved in and out of solution and affected the DNA quality intermittently. Unfortunately, data on the solubility characteristics of the major diatom storage polysaccharides are not available in the literature to determine if the concentration of polysaccharides found in the I rotula DNA samples approached saturation levels. 
The chemical dissimilarity of the isolated DNA product from the clones of I gravida and I rotula as indicated by the differences in their polysaccharide content (table 3 ) and UV spectra (figure 3), at best, only suggest ecophenotypic variation and not actual genetic differences between the species. The I rotula clones were cultured at higher temperatures $\left(15^{\circ} \mathrm{C}\right)$ than both the I gravida and $I$ nordenskioeldii clones $\left(5^{\circ} \mathrm{C}\right)$ and also had a longer period in darkness just prior to harvesting. Because of these differences in culturing conditions, no conclusions can be made concerning genotypic differences between the I gravida and I rotula clones on the basis of these results alone. Autoecological studies with these two species to determine true genetic differences, either at the level of species or merely as physiological races, would have to be performed under identical growth and harvesting conditions to eliminate these environmental influences.

The differences in polysaccharide composition of the purified DNA's between the three species of Thalassiosira probably reflects differences between species in production or utilization rates of intracellular storage polysaccharides. The most common storage polysaccharide found in the diatoms is chrysolaminarin (leucosin), a twelve-unit glucose polymer with B 1-3 and B 1-6 linkages, which has been isolated as a water soluble fraction from numerous diatoms (Allan et al. 1972) and other members of the Chrysophyta (Beattie et al. 1961). It is known that the cell concentration of storage polysaccharides in diatoms will decrease under conditions of darkness as the cells utilize this stored energy by respiration in 
the absence of light - dependent photosynthesis (Handa, 1969). Although the diatoms cultures in this study were grown under continuous light, they were placed in darkness for one to several days just prior to harvesting to facilitate cell sinking. This cessation of photosynthesis undoubtedly resulted in a period of "dark respiration" and a reduction in cell polysaccharide in all cultures. The I nordenskioeldii and I gravida cultures, however, were routinely kept in darkness several days longer than the I rotula cultures, due to their longer settling times, a function of slower sinking rates in the colder, more viscous seawater $\left(5^{\circ} \mathrm{C}\right.$ vs. $15^{\circ} \mathrm{C}$, table 1). The shorter dark period for the I rotula cultures possibly resulted in less respiratory utilization of storage polysaccharide in these cultures and the observed higher concentrations in the final DNA purifications. It is also noted that diatoms grown under blue light conditions favor the synthesis of protein over carbohydrate (Wallen, 1971a; Wallen, 1971b) suggesting that the culturing of these diatoms in the clear blue polystyrene carboys instead of clear containers decreased the polysaccharide producing potential of the diatom cells relative to culturing with white light.

When the I rotula DNA was successfully digested, the strength of the probe hybridization, as judged by intensity of the signal on the autoradiographs, was much less than either the $I$ nordenskioeldii or I gravida hybridizations. Relaxation of the hybridization conditions by lowering the hybridization and wash temperatures resulted in greater signal strength for these blots as in figure 5 but increased the non-specific DNA-DNA interactions to 
lambda DNA. Apart from various chemical problems with the DNA already discussed, lack of sufficient gene sequence homology between I rotula cpDNA and the two cpDNA probes could account for these weak signals. This would seem unlikely, however, due to the high sequence homology seen with the I gravida clones to the rbc $L$ and 23SrDNA $C$ reinhardtii gene probes. Morphologically, $I$ gravida and I rotula are very similar and this has been the basis for assuming a close genetic relationship between these two species (Hasle 1968). It would seem unlikely that $I$ gravida and $I$ nordenskioeldii are genetically more similar to each other than are I gravida and I rotula as the lack of hybridization to I rotula DNA indicates. The differences in and the conservative nature of the morphological characters used to distinguish I gravida and I rotula from $\mathrm{L}$ nordenskioeldii (i.e., number of central strutted processes, concavity of valve face, length of exterior portion of marginal processes) (Hasle 1968; Hasle 1978) indicate a genetic divergence which should also be reflected in the relative sequence homologies of their cpDNA. Also, presuming from the strength of these hybridization signals, that there is a greater genetic distance between I rotula and I gravida than between I gravida and $C$. reinhardtii would seem unsound based on the vast morphological and biochemical differences separating these two classes (Dodge, 1973; Rothschild, 1987). These inferences tend to support the idea that the lack of strong hybridization of $C$ reinhardtii cpDNA probes to $I$ rotula DNA does not indicate a difference in gene sequence but rather the presence of a chemical contaminant preventing strong DNA-DNA interactions. 
The strong hybridization of $\underline{C}$ reinhardtii chloroplast $r b c L$ and 235 rDNA gene probes to the I gravida and I nordenskioeldii DNA does, however, indicate a high sequence homology within these genes between these two classes of algae (Bacillariophyceae and Chlorophyceae) and supports the idea of the highly conserved nature of these genes across phylogenetic lines (Palmer 1985a; Palmer 1987; Palmer and Zamir 1982). Members of the algae classes Bacillariophyceae and Chlorophyceae are phylogenetically quite distant, and it has been proposed, within the framework of the endosymbiont theory, that they acquired their chloroplasts as separate endosymbiotic events either along a monophyletic track (Cavalier-Smith 1982; Cavalier-Smith 1986) or a polyphyletic one (Whatley et al. 1979). There are numerous morphological, biochemical and ontogenetic characters which separate these two classes of algae including pigment types, storage products, cell enclosures, life cycle events, and chloroplast structure (Dodge, 1973; Rothschild, 1987). Indeed, even if the evolutionary relationships of the chloroplasts as endosymbionts alone are considered between these two classes there are ample differences here at the ultrastructural level to suggest either polyphyletic origins for plastids or extreme evolutionary changes. For instance, when representative members of the diatom and the green algae groups were examined for their CDDNA configuration within the chloroplast, it was discovered that in the diatoms, the cPDNA was arranged in a ring nucleoid within the girdle lamella and in the green algae as point nucleoid clusters surrounding pyrenoids (Coleman 
1985). Also, the chloroplasts of the green algae have two encircling membranes while the diatoms have four (Dodge, 1973; Rothschild, 1987). While most of these features which delineate these two classes of algae are probably genetically controlled and there is undoubtedly vast heterogeneity within the genomes of these two classes of organisms, the primary sequences of some genes remain evolutionarily static, controlled by physiological and structural constraints. Evolution at these conservative sites proceeds very slowly and homologies extend across vast phylogenetic distances. Estimates of the conservation of the primary nucleotide sequence of the 235 rDNA gene are $92 \%$ between tobacco and maize and $78 \%$ between tobacco and the cyanophyte Anacystis (reviewed in Palmer, 1985b). Similarly for the rbc $L$ gene (large subunit for RUBISCO), high sequence homology has been found between such divergent groups as Chlamydomonas and tobacco (86-95\%) and chlorophytes and cyanobacteria (79-85\%) (reviewed in Palmer, 1985b). No estimate on the sequence homology of these genes between the diatoms studies and $\mathrm{C}$. reinhardtii can be made based on these thesis data other than that it was high enough to allow hybridization between DNAs. The restriction fragment data reported also does not indicate anything about the relative evolution of these specific genes between the classes, they are only used to identify those DNA fragments of chloroplast origin and are not indicative of restriction site homologies within the $23 S$ rDNA and $r b c L$ genes themselves. 
Other ribosomal protein genes examined in the chloroplast genome have been shown to have much lower sequence homologies across similar phylogenetic lines (i.e., angiosperms and Euglena: $39 \%$ for rps $4,43 \%$ for $r p / 2,55-58 \%$ for rps 19 , reviewed in Palmer, 1985b). Indeed, when cpDNA ribosomal protein gene segments cloned from Nicotiana tabacum (obtained from Dr. Sigiura, Nagoya University, Japan; plasmids pTB28 and pTB13 containing ribosomal protein genes $r p / 23, r p / 2, r p s 19, r p l 2, r p s 3$ and $r p / 16$ ) were used as gene probes against I rotula and I nordenskioeldii total DNA digests, no hybridization occurred, even under low stringency conditions (data not shown). Tobacco $r b c L$ and 23SrDNA probes, unfortunately, were not available for hybridization attempts to the diatom DNA.

The $I$ gravida and $I$ nordenskioeldii restriction fragment length polymorphism data (table 5 and 6) indicate inter-specific cPDNA variation greater than the variation between clones of the same species for the gene probes used. Roughly $32 \%$ of the restriction sites analyzed were found to be conserved between the two species whereas $91 \%$ and $100 \%$ were found to be conserved within the species I gravida and I nordenskioeldii respectively. This is only a nominal conclusion, however, because when only a portion of all the cpDNA restriction fragments are visualized, as is the case in these analyses, no conclusions can be made about the nature of the differences between genomes. A length mutation (multiple base deletion or addition) occurring between, say, two Hind III restriction sites in one of two DNA samples being compared, 
can appear as a restriction site change unless the complete set of cpDNA fragments resulting from the restriction enzyme digestion of the complete genome can be visualized and compared. For example, consider two hypothetical species, denoted $A$ and $B$, and species $B$ is directly evolved from species $A$. If all of the restriction fragments that comprise the chloroplast genome are visible on an agarose gel for hypothetical species $A$ and $B$, a gain of a restriction site within an $\mathrm{A}$ fragment due to a base deletion or addition, (in the evolution from species $A$ to species $B$ ) will result in two $B$ fragments whose summed sizes will equal the size of the ancestral A fragment. Conversely, if a detectable length mutation occurs within an $A$ fragment there would be an apparent loss of that fragment from species $B$ fragment pattern but the appearance of a new B fragment, smaller or larger, depending on the nature of the length mutation (increase or decrease in size). Therefore, only DNA mutations occurring at the restriction sites will result in a change in fragment number, but unless all of the fragments from the entire chloroplast genome can be visualized, no conclusions about the types of mutations can be made. The diatom cpDNA restriction fragment length polymorphisms reported here, then, only serve to indicate that change has occurred in the genomes of these two species since they last shared a common ancestor, but says nothing of the nature of that change. The evolutionary changes may have occurred by single or multiple base addition or deletion. Then, the genetic similarities between I gravida and I nordenskioeldii. reported as proportions of restriction fragments shared (table 6), should be considered as only possibilities and not actual genetic distances. 
The error involved in quantifying fragment sizes on the agarose gels due to both the variability of fragment mobilities (as shown by the standard deviation of the lambda DNA standard digests, see methods) and the inability of $0.8 \%$ agarose gels to adequately separate DNA fragments greater than approximately ten kilobase pairs, puts a lower limit of approximately $7 \mathrm{~kb}$ on the fragment size variation which can be measured between clones. The extent of the error depends on the position to which the fragment migrates, being greatest near the top of the gel due to the non-linear nature of the separation (see figure 1). Therefore, this analysis, at worst, cannot detect base deletions or additions less than seven kilobase pairs when they occur within larger fragments migrated near the top of the gel. This would possibly exclude many of the diatom DNA length mutations from being detected as the majority of length mutations occurring in cPDNA are reported to be $1-10 \mathrm{~kb}$ in length (Palmer 1987).

The significance of these results for the two clones of $I$ gravida is tempered by the fact that the two cultures were isolated from the same area at the same time (see table 1) and may represent genetically identical asexual progeny of one another. It is interesting, though not surprising considering the slow rate of evolutionary change in the chloroplast genome, that their separation in culture for ten years did not produce significant observable cPDNA differences. Two of the three clones of $I$ nordenskioeldii (clones Zud2 and X1) which exhibited complete sequence homology for those areas of the chloroplast genome examined, were isolated from 
different water masses (north and south of Cape Cod, Massachusetts). Although it is conceivable that these water masses could mix and exchange biota via the Cape Cod Canal or around the peninsula, it is unlikely that $X 1$ and Zud2 represent recent clonal siblings. It is not known, however, whether the extent of the intraspecific variation seen in this study is truly representative of the entire diatom populations in nature. To examine this problem would indeed be a Herculean task, considering the magnitude of geographically contiguous diatom populations and the complexity and expense of the DNA isolation and characterization methods.

The chloroplast genome size estimate for I rotula (clone F4) of 147 kilobase pairs should be considered approximate. The value is the sum of the sizes of the fragments produced when the presumptive chloroplast DNA from the $\mathrm{CsCl-Hoechst} \mathrm{dye} \mathrm{gradient} \mathrm{is}$ digested with a single restriction enzyme. All bands are assumed to be chloroplast DNA with no contribution from mitochondrial and nuclear. It is possible, though, that there is present some of this contaminating DNA. The presumptive cpDNA band from the $\mathrm{CsCl}$ Hoechst dye gradient was removed as a very tight and distinct fluorescing band indicating that the DNA was of homogeneous physical and chemical character, but it is reasonable to assume that in removing the cPDNA band from the centrifuge tube, some contaminating, non-chloroplast DNA was removed also. This is seen in figure (F4 1-3 autorad) where the Chlamvdomonas cpDNA gene probe hybridized to small amounts of cpDNA which contaminated the lower two CsCl-Hoechst gradient bands, F4-2 and F4-3. If cpDNA 
contaminated the lower two bands in the $\mathrm{CsCl}-\mathrm{Hoechst}$ gradient, it is prudent to assume that the opposite occurred: DNA from these two lower bands may have contaminated the upper cpDNA band. Rochaix (Rochaix 1982) has identified contaminating mitochondrial DNA and nuclear ribosomal DNA bands in Bam $\mathrm{HI}$ digests of Chlamydemonas cpDNA purified through two $\mathrm{CsCl}$ gradients. The I rotula cpDNA was not probed for contaminating mitochondrial or nuclear DNA and it is possible that some of the summed fragments originated from these two genomes. The chloroplast genome size estimate of 147 kilobase pairs, even if considered as a possible overestimate of the true genome size is within the range of sizes reported for other chromophytes such as: Olisthodiscus luteus, 150 kb (Aldrich and Cattolico 1981); Vaucheria sessilis, $125 \mathrm{~kb}$ (Hermann et al. 1980); Plylaiella littoralis, $140 \mathrm{~kb}$; Sohacelaria sp., $156 \mathrm{~kb}$ (Dalmon et al. 1983); Coscinodiscus granii, $120 \mathrm{~kb}$; Odontella sinensis, $118 \mathrm{~kb}$ (Kowallik 1990); and Skeletonema costatum, $120 \mathrm{~kb}$ (Stabile et al. 1990).

Estimates of DNA content per cell varied over a four-fold range for the three species of Ihalassiosira (table 3) and are within the range reported for other diatoms (Holm-Hansen 1969). HolmHansen's DNA measurements were made on methanol and acetone extracted diatom lysates. These were then reacted with DABA $(3,5$ diaminobenzoic acid) and the resulting fluorescence measured and considered proportional to DNA concentration. There was no mention made, however, of the efficiency of the extraction procedure and whether all of the cell contents were exposed to the DABA (Holm- 
Hansen et al. 1968). Holm-Hansen's DNA values were correlated with cellular carbon values for several species of phytoplankton. It was found that cellular DNA content was one to three percent of the total carbon content, but no correlation statistics or linear regression equation was given for this relationship (Holm-Hansen 1969).

As an internal check on these values, the cellular DNA content for clones HB3 and TTG2 was also estimated using Holm-Hansen's empirical formulas relating the carbon content to DNA content of diatoms (Holm-Hansen 1969) (Table 7). Although carbon values were not determined for these diatom clones, estimates using the empirical formula of Smayda [Smayda, 1965] relating the plasma volume (total volume minus the vacuole volume) to carbon content were used and considered reasonable for nutrient replete cell growth (Strathman 1967) but neglecting the effects of temperature (Eppley, 1972). The DNA content measured for I gravida clone TTG2 (1.4 pg/cell) falls within the range estimated by Holm-Hansen's above-mentioned relationship of carbon content to DNA content $(0.89$ - $2.67 \mathrm{pg} / \mathrm{cell}$ ) but falls short for I nordenskioeldii. clone HB3 (0.35 $\mathrm{pg} / \mathrm{cell}$ vs. estimated value of 1.09-3.27 pg/cell).

It is reasonable to assume that these DNA content estimates are low due to the many steps in the DNA purification protocol in which losses and inaccurate measurements could occur. These include cell losses during centrifuging and decanting of the twenty liter culture following aliquot removal for cell counts, and incomplete cell lyses in french press after cell count. Microscopic observation of the french press lysate revealed that often greater 
than ten percent of the diatom cells remained intact and thus did not contribute their DNA to the final yield. After the cell lysing, the numerous phenol-chloroform extractions, ethanol precipitations and $\mathrm{CsCl}$ gradients probably resulted in significant losses of DNA. Both these factors, overestimation of numbers of cells contributing DNA, and loss of DNA through purification steps, would tend to lower the DNA per cell estimate.

\section{Conclusion}

Chemical and spectrophotometeric analysis indicates a high level of polysaccharide contamination for the I rotula DNA samples which may have prevented its hybridization to the $C$ reinhardtii cpDNA probes. As a result, restriction fragment length polymorphism data for this species are not presented and a genetic analysis of the I rotula and I gravida species controversy is not possible at this time. The $\mathrm{C}$ reinhardtii cpDNA probes did hybridize sufficiently well however to the DNA purified from the $I$. nordenskioeldii and I gravida clones to allow intra- and interspecific comparisons here. As has been found in other studies, there is a greater similarity of cpDNA sequences within a species than between species. While these results indicate genetic differences between the clones studied, no conclusions can be made of the nature of the differences. The strong hybridization signals at high stringency conditions for the 23srDNA and rbc $L$ gene probes from C. reinhardtii cpDNA to the DNA of the diatom clones indicates high sequence homology and supports the idea that these genes are highly conserved across vast phylogenetic distances (Palmer 1987). 
The species identification for the clones of $I$ gravida and $I$ rotula, as described in methods, are assumed to differentiate the two taxa in this study based on the standard morphological criteria for diatoms. These taxonomic criteria, which recognize relatively "stable" characters (areola pattern, size and shape of girdle bands and overall size and shape of frustule), can to a great degree be controlled by external conditions, and, consequently, are likely to be of little taxonomic utility for distinguishing between I gravida and I rotula. Many field observations of net tows taken in areas which are considered transition zones for the two species (Hasle 1976) reveal mixures of both I gravida and I rotula cell types (Paasche 1961; Syvertsen 1977) sometimes present within the same colony (Hasle et al. 1971). Indeed, the I rotula clones used in this study were observed to have valves with a mixture of areola pattern types, showing the "I rotula" type pattern near the valve center and the "I gravida" type pattern near the valve margins (pers. observ.). These clones, however, were grown at $15^{\circ} \mathrm{C}$, several degrees above what is considered the temperature of the transition zone $\left(\sim 3\right.$ to $\left.10^{\circ} \mathrm{C}\right)$. Whatever the physiological reasons behind this morphological variability are, though, it is clear that these taxonomic criteria are not significantly rigorous to distinguish between I gravida and I rotula under all ecological conditions.

The problems enountered in identifying and distinguishing between closely related species of diatoms are a result of a classification system based largely on the typological species concept, more specifically, based on the species defined by a 
specific set of morphologic characters (Makarova 1980; Mayr 1970). This method of classification is necessary due to the relatively few or non-existant ecological, behavioral, ontogenetic and biochemical characters available to the diatom systematist to group this huge array of single celled eukaryotes. This is complicated by the fact that the diatom's primary mode of reproduction is by asexual fission, thus eliminating reproductive compatability and the biological species concept as a criteria by which to classify species. All that is left to distinguish between species of diatoms is morphological characters.

This study, and others like it, has shown that molecular characterization of an organism's genome can be used to infer phylogenetic distances between and within most levels of taxa. If evolution in its strictest sense is considered to be the gradual accumulation of mutations within a population's gene pool through geologic time, then, by quantifying and characterizing these mutations, phylogenetic distances and relationships can be quantified, thus building a taxonomic system based on evolutionary relationships and trends. The concept of a species, as defined by Florkin (1966) is particularly salient here:

... a species [consists of] groups of individuals with more or less similar combinations of sequences of purine and pyrimidine bases in their macromolecules of DNA, and with a system of operators, controllers and repressors leading to the biosynthesis of similar sequences of amino acids, the integration of which, in one cell, or in a number of variably differentiated cells, leads to similar stuctural and functional characteristics, adapted to the ecological niche in which the species flourishes. 
This definition can be considered as an addendum to the biological species concept as reviewed by Mayr (1970) which defines a species, in part, as a protected gene pool. By including the molecular functions of the genes and the gene products (proteins), Florkin implies in his definition that species can be defined at the molecular level. A system of taxonomic classification which uses molecular as well as other types of character data (morphological, ontogenetic, behavioral, biochemical, etc.) would benefit by incorporating information on the evolutionary trends and distances of the individuals within the lineages considered.

The method of total DNA purification used in this study was satisfactory for isolating large amounts of high molecular weight DNA. It is fairly rapid and inexpensive, the only two pieces of expensive equipment required being an ultracentrifuge and a french press. The effectiveness of the method, however, depends heavily on the nature and physiologic condition of the species of algae studied. The interferences due to contaminating substances, such as polysaccharides, must be avoided by carefully controlling the initial growth conditions of the organism or by using suitable methods to eliminate the known contaminant. In this study, possibly longer periods in the dark for the I rotula clones or further purifying the DNA by affinity chromatography, would have solved the problem of interfering substances.

The method of restriction fragment length polymorphism employed here has advantages over methods used previously for 
molecular systematic analysis such as DNA-DNA hybridization (Britten et al, 1974) and iso-enzyme electrophoresis (Murphy and Guillard, 1976). Compared to the DNA-DNA hybridization method, the RFLP method requires less DNA (ug vs. mg quantities) and because the DNA-DNA hybridization rates are highly dependent on the physical purity of the DNA preparations, these data are suspect when comparisons are made between samples with possibly different levels of interfering substances. The RFLP method, on the other hand, because it is not rate dependent, will not be affected by impurities unless their presence prohibits hybridization entirely at the required conditions of stringency. Isoenzyme electrophoresis, a method of inferring genetic relatedness as a function of the electrophoretic mobility of selected groups of enzymes, is a simpler, quicker method than RFLP, but detects only those genetic differences which are translated into protein, i.e., the coding regions of the genes. The RFLP method, because it analyzes the genetic material (DNA) directly, is able to detect base mutations which occur in all coding and non-coding regions. Mutations in the noncoding, regulatory regions of the genome, because they are not translated into protein products, can only be analyzed by direct means, and would be missed by an analyses of the translated gene product. Also, most of the point mutations in DNA occur at the third (silent) position of the nucleotide codon ( $\mathrm{Nei}$ and $\mathrm{Li}$ 1979), and possibly would not effect the structure of the analyzed protein.

The RFLP method, however, is not without its problems, and will probably be rapidly supplanted in the future by more efficient 
means of analyzing genetic evolutionary change (Olsen 1990). Aside from the many technical problems already discussed for the RFLP method (purity, laborious methods, expense), there is the question of determining the nature and extent of the genetic change. The RFLP method used in this study, as already noted, does not describe the actual structural differences in the cPDNA but merely shows that differences exist. In its most rigorous form, RFLP analysis compares restriction fragment patterns of the entire genome (requiring highly purified $\operatorname{cpDNA}$ ) and identifies point and length mutations, thereby describing these differences with much less ambiguity. To detect rearrangements of the genome, a common evolutionary change in the algal lineages (Palmer 1985b), RFLP analysis and southern blot hybridizations can be enhanced with genome mapping to determine relative positions of specific genes (Palmer 1986). Also, using polymerase chain reaction (PCR) techniques, specific genes located on short portions of DNA can be amplified to obtain the required large amounts of material. In this way the nucleotide sequences of specific genes can be elucidated and their mode and tempo of evolution be determined. Using these methods, a clearer picture of the degree of genetic relatedness between extant algal species can be obtained from which lines of evolutionary descent can eventually be inferred. 
APPENDIX A (TABLES)

55 
Table 1

Diatom culture data

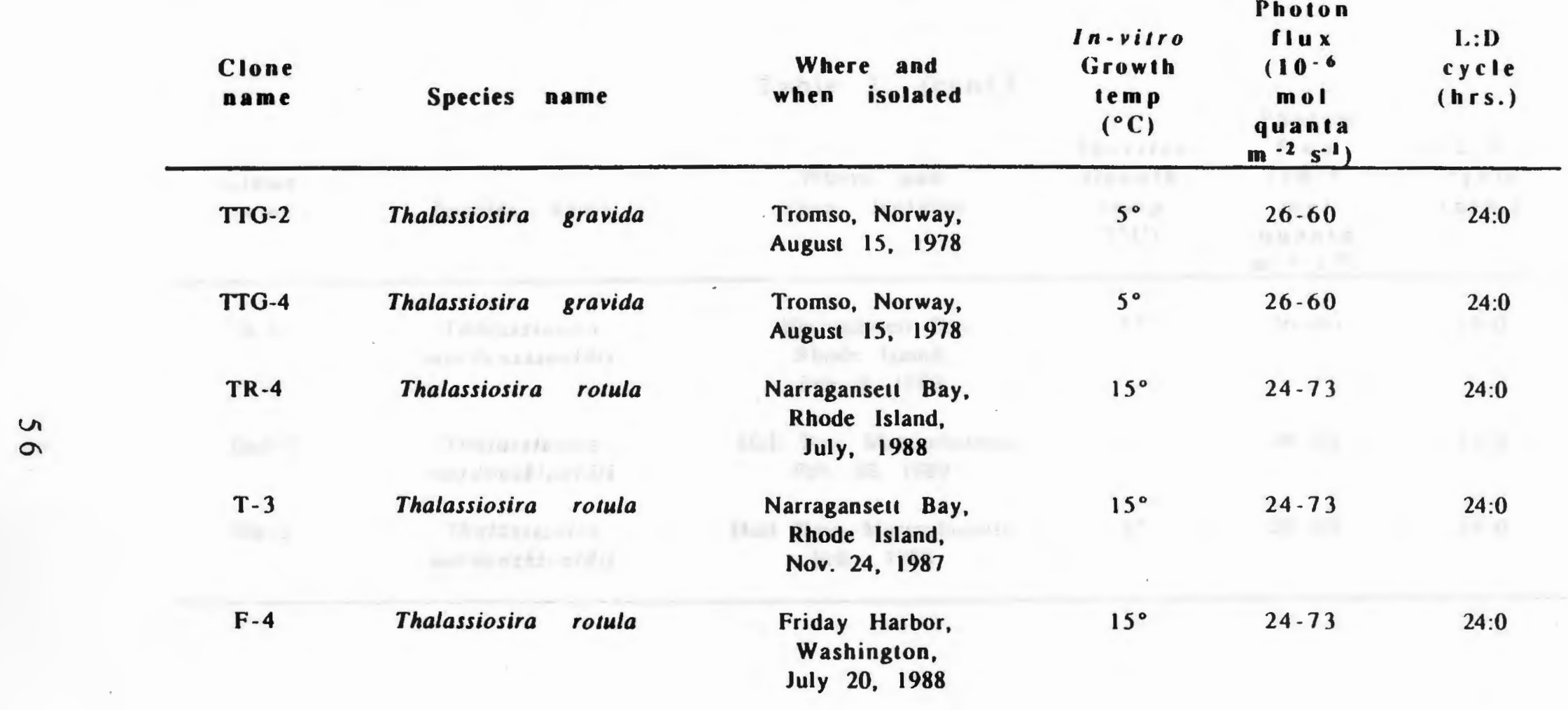


Table 1. (cont.)

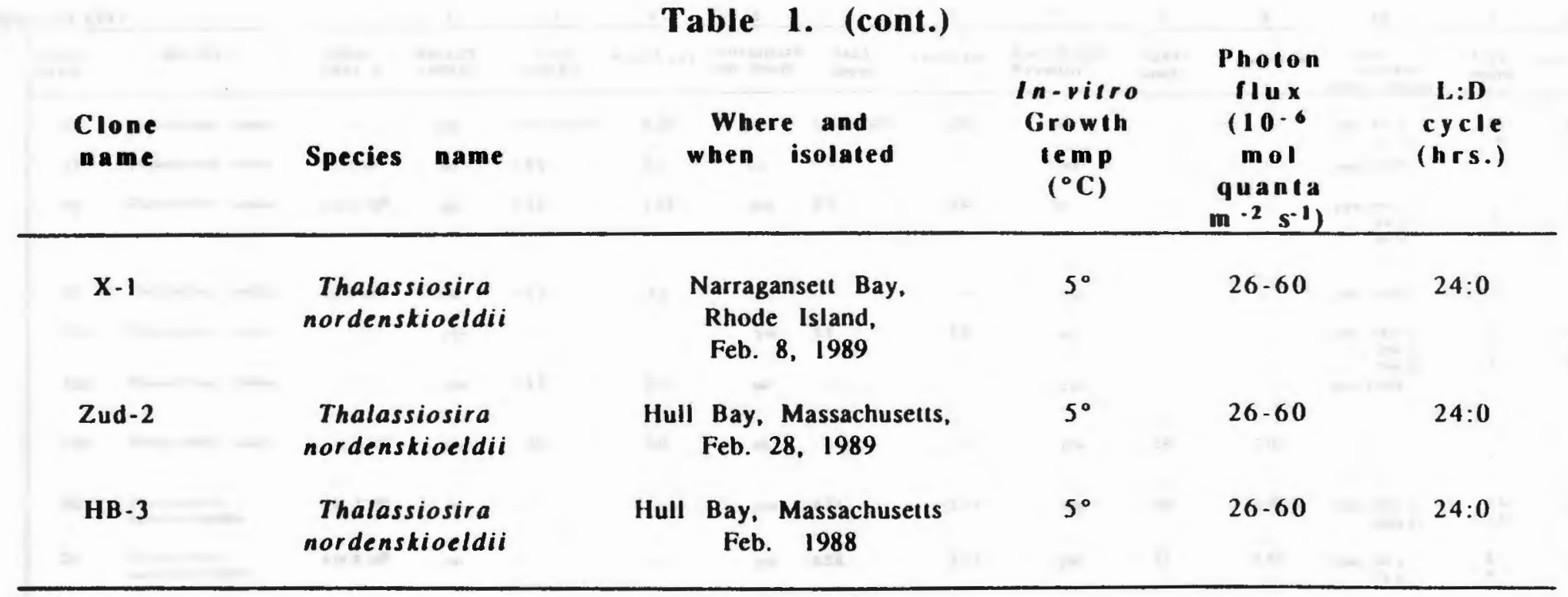


Table 2

Summary of DNA purification steps for diatom clones and some data.

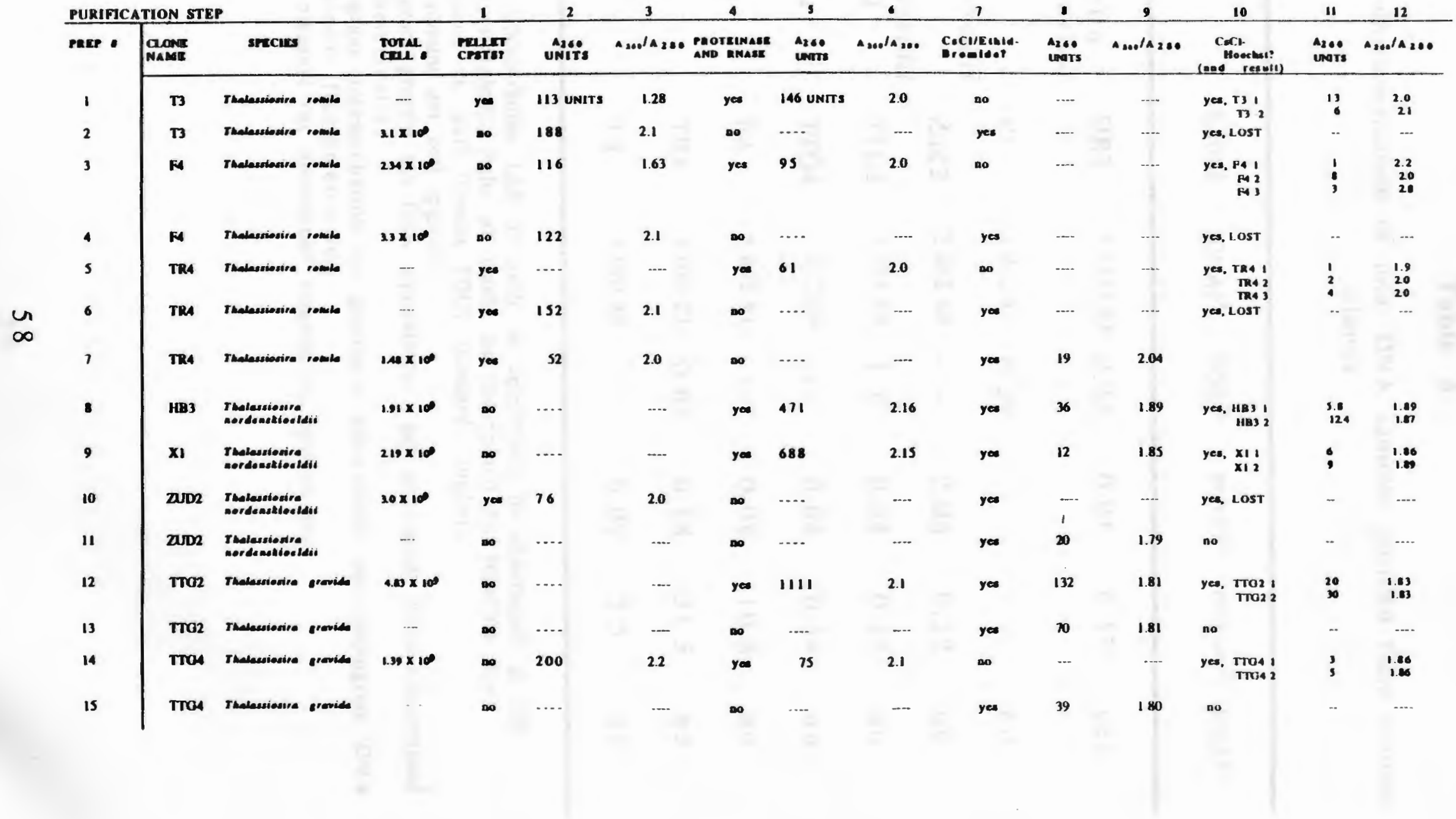




\section{Table 3}

Chemical characterization of total DNA samples purified from diatom clones.

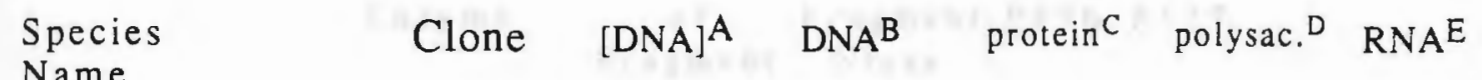

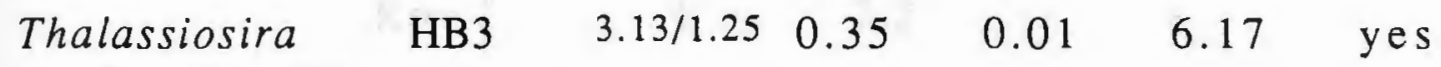
nordenskioeldii

$T$.

$$
\mathrm{X} 1
$$

$1.0 / 2.43$

0.28

$-\cdot$

no

nordenskioeldii

$T$.

Zud2

$2.0 / 2.63 \quad \ldots$

0.06

0.52 no

nordenskioeldii

T. gravida

TTG2

$1.0 / 1.69 \quad 1.4$

0.04

0.47

no

T. gravida

TTG4

$1.0 / 2.04 \quad \ldots$

0.08

0.44 no

T. rotula

F4

$5.6 / 2.81 \quad \ldots$

0.08

10.8

no

T. rotula

TR4

$1.0 / 0.21 \quad 0.65$

0.18

31.5

no

T. rotula

T3

$2.0 / 0.80 \quad \ldots$

0.09

5.5

no 


\section{Table 4}

Number and sizes of fragments produced which hybridized to $\mathrm{C}$. reinhardtii probes for all diatom DNA samples digested with ten restriction enzymes.

\begin{tabular}{|c|c|c|c|c|}
\hline $\begin{array}{c}\text { Restriction } \\
\text { Enzyme }\end{array}$ & $\begin{array}{c}\text { Number } \\
\text { of } \\
\text { Fragment } \\
\quad s \\
\end{array}$ & $\begin{array}{c}\text { Fragment } \\
\text { Sizes } \\
\text { (kbp) }\end{array}$ & P $67 \mathrm{~b}$ & P 177 \\
\hline Kpn I & 1 & 7.2 & & + \\
\hline Bgl II & 3 & $\begin{array}{c}20.5 \\
17.5 \\
8.4\end{array}$ & + & $\begin{array}{l}+ \\
+\end{array}$ \\
\hline Cla I & 4 & $\begin{array}{c}14.5 \\
11.5 \\
9.0 \\
7.9\end{array}$ & $\begin{array}{l}+ \\
+ \\
+\end{array}$ & + \\
\hline Eco RI & 6 & $\begin{array}{c}10.5 \\
7.2 \\
6.6 \\
6.2 \\
5.5 \\
1.7\end{array}$ & $\begin{array}{l}+ \\
+ \\
+\end{array}$ & $\begin{array}{l}+ \\
+ \\
+\end{array}$ \\
\hline Eco RV & 7 & $\begin{array}{c}17.5 \\
16.0 \\
12.2 \\
11.3 \\
10.5 \\
8.5 \\
7.8\end{array}$ & $\begin{array}{l}+ \\
+\end{array}$ & $\begin{array}{l}+ \\
+ \\
+ \\
+ \\
+ \\
+\end{array}$ \\
\hline Hind III & 5 & $\begin{array}{l}7.2 \\
3.2 \\
2.6 \\
2.4 \\
2.2\end{array}$ & $\begin{array}{l}+ \\
+ \\
+ \\
+\end{array}$ & + \\
\hline
\end{tabular}


Table 4 (cont.)

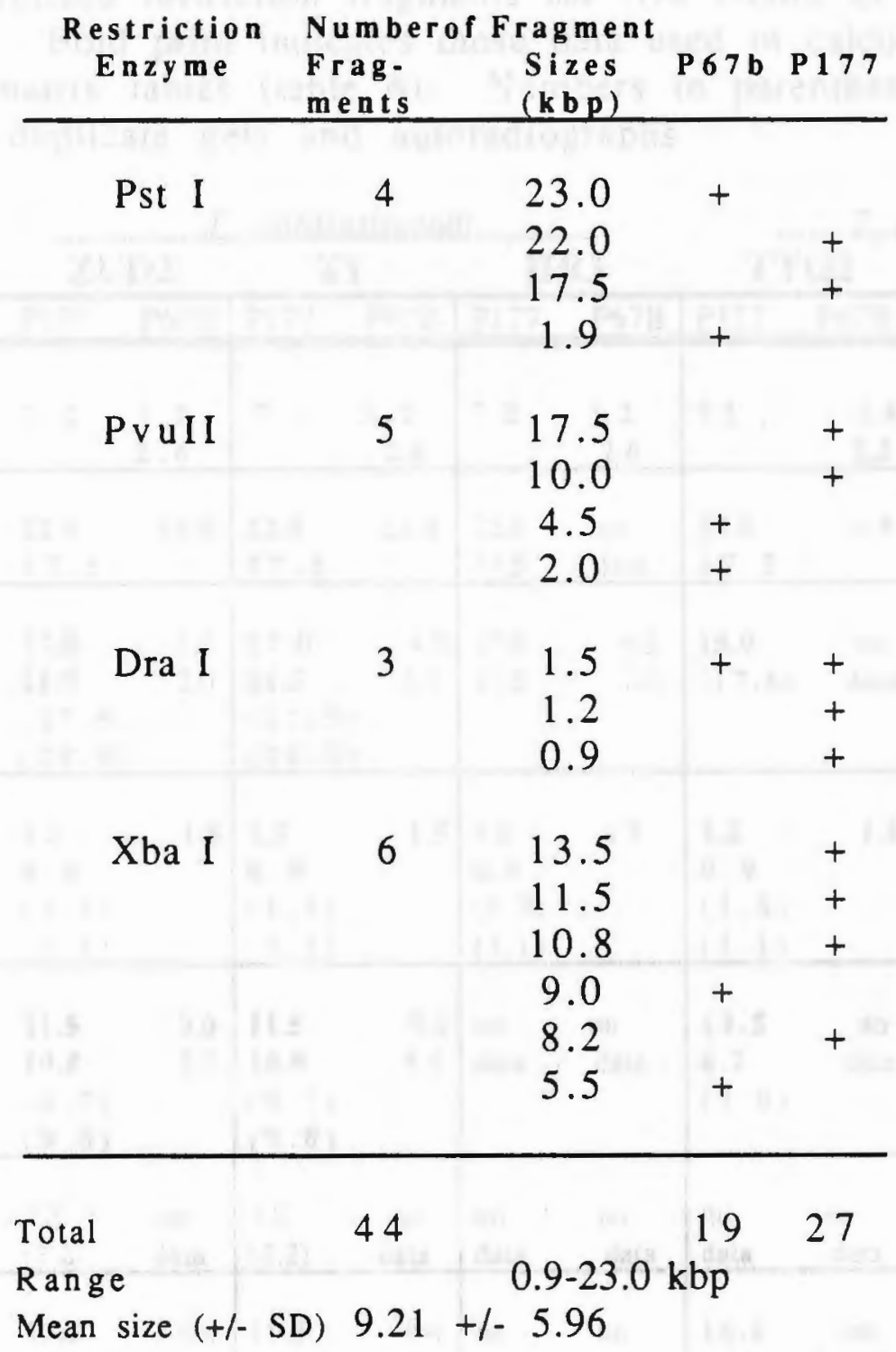


Table 5

Data from autoradiographs in figures 7 and 8 showing a comparison of the hybridized restriction fragments for five clones of two species of diatoms. Bold print indicates those data used in calculating similarity matrix tables (table 6). Numbers in parentheses indicate data from duplicate gels and autoradiographs

\begin{tabular}{|c|c|c|c|c|c|c|c|c|c|c|}
\hline \multirow{3}{*}{$\begin{array}{l}\text { species } \\
\text { clone: } \\
\text { probe: }\end{array}$} & \multicolumn{6}{|c|}{ T. nordenskioeldii } & \multicolumn{4}{|c|}{ T. gravida } \\
\hline & \multicolumn{2}{|c|}{ ZUD2 } & \multicolumn{2}{|c|}{$\mathrm{X} 1$} & \multicolumn{2}{|c|}{ HB3 } & \multicolumn{2}{|c|}{ TTG2 } & \multicolumn{2}{|c|}{ TTG4 } \\
\hline & $\mathrm{P} 177$ & P67B & $\mathrm{P} 177$ & P67B & P177 & P67B & $\mathrm{P} 177$ & P67B & P177 & P67B \\
\hline Hind III & 7.2 & $\begin{array}{l}3.2 \\
2.6 \\
\end{array}$ & 7.2 & $\begin{array}{r}3.2 \\
2.6 \\
\end{array}$ & 7.2 & $\begin{array}{r}3.2 \\
2.6 \\
\end{array}$ & 7.2 & $\begin{array}{l}2.4 \\
2.2 \\
\end{array}$ & 7.2 & $\begin{array}{l}2.4 \\
2.2 \\
\end{array}$ \\
\hline Pst I & $\begin{array}{l}22.0 \\
17.5 \\
\end{array}$ & 23.0 & $\begin{array}{l}22.0 \\
17.5 \\
\end{array}$ & 23.0 & $\begin{array}{l}22.0 \\
17.5 \\
\end{array}$ & $\begin{array}{l}\text { no } \\
\text { data }\end{array}$ & $\begin{array}{l}22.0 \\
17.5 \\
\end{array}$ & 1.9 & $\begin{array}{l}22.0 \\
17.5 \\
\end{array}$ & 1.9 \\
\hline Pvu II & $\begin{array}{l}17.0 \\
11.5 \\
(17.5) \\
(10.0) \\
\end{array}$ & $\begin{array}{l}4.5 \\
2.0\end{array}$ & $\begin{array}{l}17.0 \\
11.5 \\
(17.5 \\
110.0 \\
\end{array}$ & $\begin{array}{l}4.5 \\
2.0\end{array}$ & $\begin{array}{l}17.0 \\
11.5\end{array}$ & $\begin{array}{l}4.5 \\
2.0\end{array}$ & $\begin{array}{l}15.0 \\
(17.5)\end{array}$ & $\begin{array}{l}\text { no } \\
\text { data }\end{array}$ & $\begin{array}{l}15.0 \\
(17.5)\end{array}$ & $\begin{array}{r}\text { no } \\
\text { data }\end{array}$ \\
\hline Dra I & $\begin{array}{l}1.5 \\
0.9 \\
(1.7) \\
(1.1) \\
\end{array}$ & 1.5 & $\begin{array}{l}1.5 \\
0.9 \\
(1.7) \\
(1.1) \\
\end{array}$ & 1.5 & $\begin{array}{l}1.5 \\
0.9 \\
(1.7) \\
(1.1) \\
\end{array}$ & 1.5 & $\begin{array}{l}1.2 \\
0.9 \\
(1.4) \\
(1.1) \\
\end{array}$ & 1.5 & $\begin{array}{l}1.2 \\
0.9 \\
(1.4) \\
(1.1) \\
\end{array}$ & 1.5 \\
\hline Xba I & $\begin{array}{l}11.5 \\
10.8 \\
(9.7) \\
(9.0) \\
\end{array}$ & $\begin{array}{l}9.0 \\
5.5\end{array}$ & $\begin{array}{l}11.5 \\
10.8 \\
(9.7) \\
(9.0) \\
\end{array}$ & $\begin{array}{l}9.0 \\
5.5\end{array}$ & $\begin{array}{l}\text { no } \\
\text { data }\end{array}$ & $\begin{array}{l}\text { no } \\
\text { data }\end{array}$ & $\begin{array}{l}13.5 \\
8.2 \\
(7.8)\end{array}$ & $\begin{array}{c}\text { no } \\
\text { data }\end{array}$ & $\begin{array}{l}13.5 \\
8.2 \\
(7.8)\end{array}$ & $\begin{array}{c}\text { no } \\
\text { data }\end{array}$ \\
\hline Kpn I & $\begin{array}{l}7.2 \\
(7.2) \\
\end{array}$ & $\begin{array}{l}\text { no } \\
\text { data }\end{array}$ & $\begin{array}{l}7.2 \\
(7.2) \\
\end{array}$ & $\begin{array}{r}\text { no } \\
\text { data }\end{array}$ & \begin{tabular}{|l} 
no \\
data
\end{tabular} & $\begin{array}{l}\text { no } \\
\text { data }\end{array}$ & $\begin{array}{l}\text { no } \\
\text { data }\end{array}$ & $\begin{array}{l}\text { no } \\
\text { data }\end{array}$ & $\begin{array}{l}\text { no } \\
\text { data }\end{array}$ & $\begin{array}{l}\text { no } \\
\text { data }\end{array}$ \\
\hline Bgl II & $\begin{array}{l}17.5 \\
16.0 \\
(20.5) \\
(17.5) \\
\end{array}$ & 8.4 & $\begin{array}{l}17.5 \\
16.0 \\
(20.5 \\
(17.5 \\
\end{array}$ & 8.4 & $\begin{array}{l}\text { no } \\
\text { data }\end{array}$ & $\begin{array}{l}\text { no } \\
\text { data }\end{array}$ & $\begin{array}{l}16.0 \\
14.0 \\
(20.5) \\
(17.5) \\
\end{array}$ & $\begin{array}{l}\text { no } \\
\text { data }\end{array}$ & $\begin{array}{l}16.0 \\
14.0 \\
(20.5) \\
(17.5) \\
\end{array}$ & $\begin{array}{l}\text { no } \\
\text { data }\end{array}$ \\
\hline Cla I & $\begin{array}{l}8.0 \\
(7.9) \\
\end{array}$ & $\begin{array}{l}9.0 \\
7.9 \\
\end{array}$ & $\begin{array}{l}8.0 \\
(7.9) \\
\end{array}$ & $\begin{array}{l}9.0 \\
7.9 \\
\end{array}$ & $\begin{array}{l}\text { no } \\
\text { data }\end{array}$ & $\begin{array}{l}\text { no } \\
\text { data }\end{array}$ & $\begin{array}{l}(14.5) \\
(11.5) \\
\end{array}$ & $\begin{array}{r}\text { no } \\
\text { data }\end{array}$ & $\begin{array}{l}(14.5) \\
(11.5) \\
\end{array}$ & $\begin{array}{r}\text { no } \\
\text { data } \\
\end{array}$ \\
\hline Eco RI & 7.2 & $\begin{array}{r}10.5 \\
1.7 \\
\end{array}$ & 7.2 & $\begin{array}{r}10.5 \\
1.7 \\
\end{array}$ & 7.2 & $\begin{array}{r}10.5 \\
1.7 \\
\end{array}$ & $\begin{array}{l}5.5 \\
6.6 \\
\end{array}$ & & $\begin{array}{l}6.2 \\
6.6 \\
\end{array}$ & \\
\hline Eco $R$ & $\begin{array}{l}17.5 \\
16.0 \\
10.5\end{array}$ & 17.5 & $\begin{array}{l}17.5 \\
16.0 \\
10.5\end{array}$ & 17.5 & $\begin{array}{l}17.5 \\
16.0 \\
10.5\end{array}$ & 17.5 & $\begin{array}{l}11.3 \\
8.5 \\
7.8\end{array}$ & 12.2 & $\begin{array}{l}11.3 \\
8.5 \\
7.8\end{array}$ & 12.2 \\
\hline
\end{tabular}




\section{Table 6}

Similarity matrix table calculated from equation $\mathrm{S}=$ $2 \mathrm{~N}_{\mathrm{x} y} / \mathrm{N}_{\mathrm{x}}+\mathrm{N}_{\mathrm{y}}$ (see text for details). The numbers above the diagonal indicated the total number of shared restriction fragments $\left(\mathrm{N}_{\mathrm{xy}}\right)$, the numbers below the diagonal, the proportion of shared restriction fragments (S), and the numbers along the diagonal in parentheses are the total number of restriction fragments considered from each set $\left(\mathrm{N}_{\mathrm{x}}\right.$ and $\left.\mathrm{N}_{\mathrm{y}}\right)$.

probes $\mathrm{P} 67 \mathrm{~B}$ and $\mathrm{P} 177$

\begin{tabular}{c|cccc}
\multicolumn{1}{c}{} & Zud2 & X1 & TTG2 & TTG4 \\
\cline { 2 - 5 } Zud2 & $(21)$ & 21 & 7 & 7 \\
X1 & 1.00 & $(21)$ & 7 & 7 \\
TTG2 & 0.32 & 0.32 & $(23)$ & 21 \\
TTG4 & 0.32 & 0.32 & 0.91 & $(23)$
\end{tabular}

probe $\underline{\mathrm{P} 177}$ only

\begin{tabular}{c|cccc}
\multicolumn{1}{c}{} & Zud2 & X 1 & TTG2 & TTG4 \\
\cline { 2 - 5 } Zud2 & $(15)$ & 15 & 6 & 6 \\
X1 & 1.00 & $(15)$ & 6 & 6 \\
TTG2 & 0.38 & 0.38 & $(17)$ & 15 \\
TTG4 & 0.38 & 0.38 & 0.94 & $(17)$
\end{tabular}

probe $\underline{\text { P67B }}$ only

\begin{tabular}{c|cccc}
\multicolumn{1}{c}{} & Zud2 & X1 & TTG2 & TTG4 \\
\cline { 2 - 5 } Zud2 & $(7)$ & 7 & 1 & 1 \\
X1 & 1.00 & $(7)$ & 1 & 1 \\
TTG2 & 0.15 & 0.15 & $(6)$ & 6 \\
TTG4 & 0.15 & 0.15 & 1.00 & $(6)$
\end{tabular}




\section{Table 7}

Cell carbon and cell DNA estimates for $\mathrm{T}$ nordenskioeldii clone HB3 and $\mathrm{T}$. gravida clone TTG2 based on mensuration and empirical formulae.

T. nordenskioeldii (HB3) T gravida_TTG2)

\begin{tabular}{lll}
\hline Plasma volume(um³) & 927.9 & 744.4 \\
Carbon (pg/cell)b & 108.9 & 89.5 \\
DNA (pg/cell)c & $1.09-3.27$ & $0.89-2.67$ \\
number cells & 12 & 20 \\
measured & & \\
DNA (pg/cell)d & 0.35 & 1.40 \\
\hline
\end{tabular}

a - calculated according to Smayda [Smayda, 1965]: PV $=\left(\right.$ surface area, um $\left.{ }^{2}\right)$

(cytoplasmic layer thickness $(=1 \mathrm{um}))+(0.10)\left(\right.$ Total cell vol, $\mathrm{um}^{3}$ )

b - calculated according to Strathman [Strathman, 1967 \#130] : $\log C=$ $0.892(\log P V)-0.610$

c - estimated as one to three percent carbon content of cell after Holm-Hansen [Holm-Hansen, $1969 \# 76$ ] .

d - from table 3, this thesis 
APPENDIX B (FIGURES)

65 
Figure 1. Standard deviation of the mean of the mobilities of triplicate Hind III-lambda DNA digests versus the distance migrated on $0.8 \%$ agarose gel. 
Figure 1

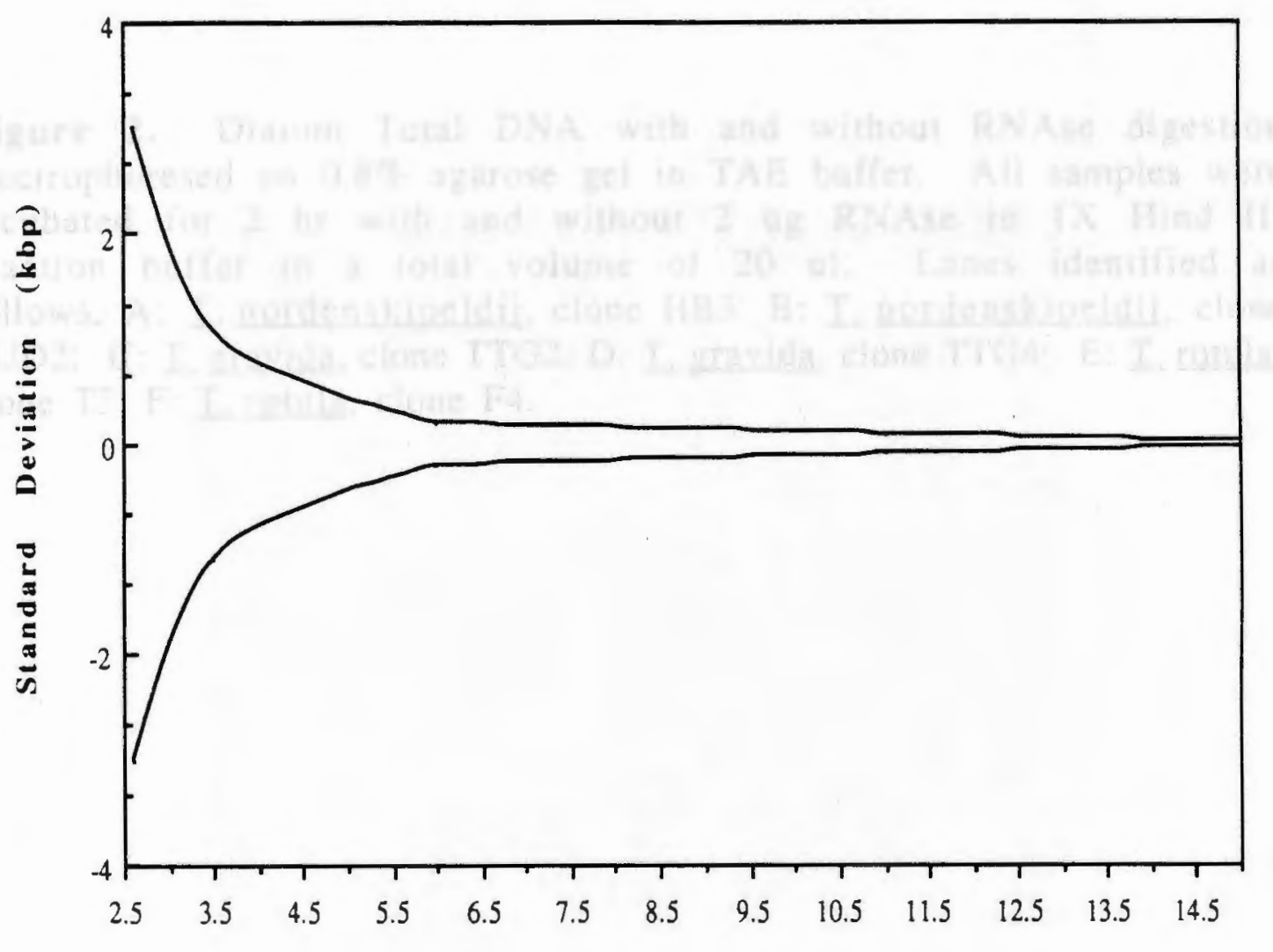

Mobility (cm) 
Figure 2. Diatom Total DNA with and without RNAse digestion electrophoresed on $0.8 \%$ agarose gel in TAE buffer. All samples were incubated for $2 \mathrm{hr}$ with and without $2 \mathrm{ug}$ RNAse in $1 \mathrm{X}$ Hind III reaction buffer in a total volume of 20 ul. Lanes identified as follows, A: $\mathbf{T}$. nordenskioeldii, clone HB3; B: $\underline{T}$ nordenskioeldii, clone ZUD2; C: T. gravida, clone TTG2; D: T. gravida, clone TTG4; E: T. rotula, clone T3; F: T. rotula, clone F4. 
Figure 2

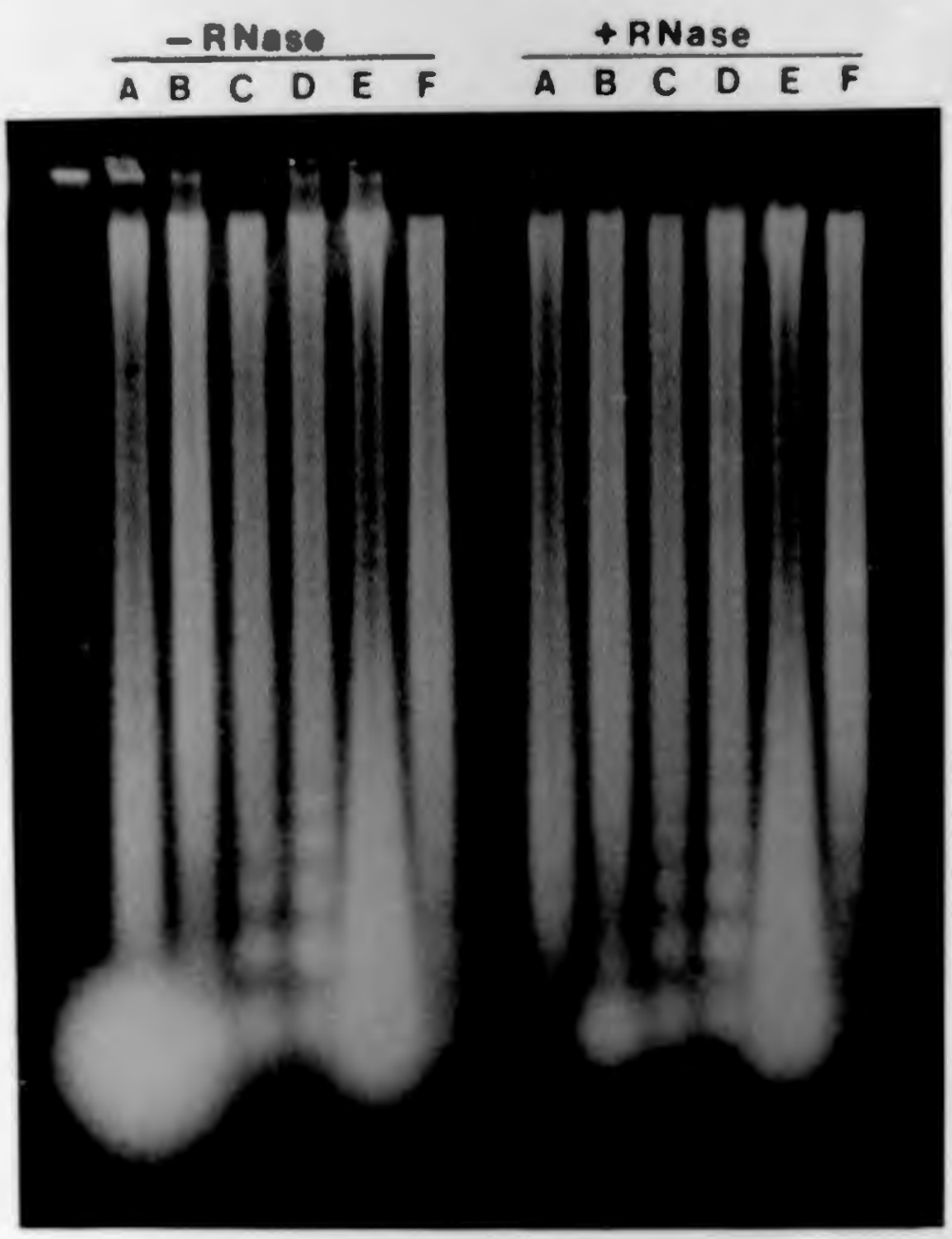


Figure 3. UV spectra of diatom total DNA samples and salmon sperm DNA. Scan range 300 to $200 \mathrm{~nm}$. Optical density values increase upwards on $y$-axis. 
Figure 3

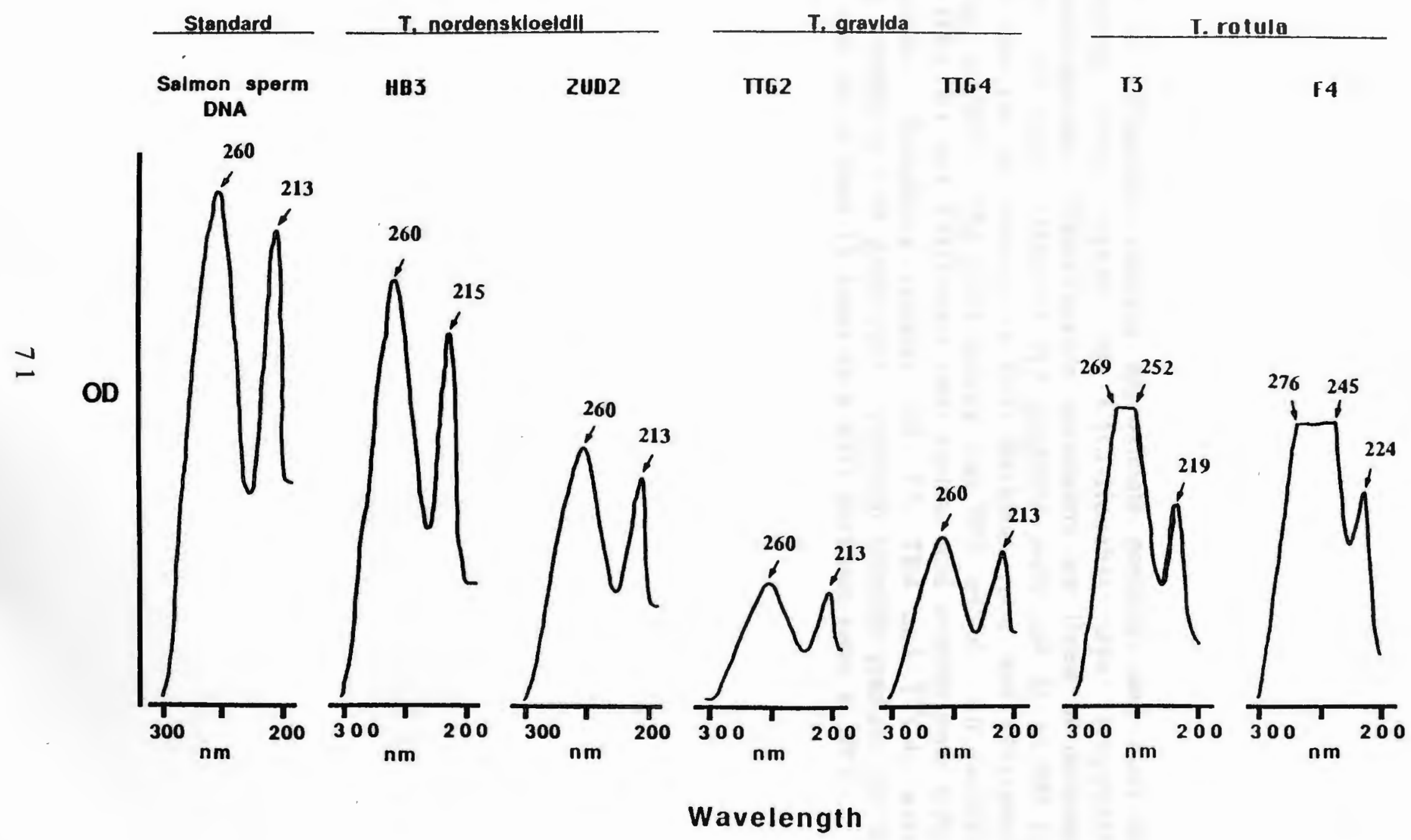


Figure 4. Diagrams showing approximate positions and sizes of fluorescing DNA bands in CsCl-Hoechst dye isopycnic ultracentrifugations. Centrifugation parameters are listed in methods section. All $\mathrm{CsCl}$ - Hoechst dye gradients were run at 40,000 to $45,000 \mathrm{rpm}$ for 48 hours in a $80 \mathrm{Ti}$ Beckman rotor and ultraspeed centrifuge at $20^{\circ} \mathrm{C}$. The $\mathrm{CsCl}$ density was $90 \% \mathrm{wt} / \mathrm{vol}$. All samples except HB3, X1 and TTG2 were total nucleic acid without prior $\mathrm{CsCl}$ purification. Remaining samples (F4, T3, TR4 and TTG4) were initially banded in $1.65 \mathrm{~g} / \mathrm{ml} \mathrm{CsCl}$ - ethidium bromide gradient run at $40,000 \mathrm{rpm}$ for at least 12 hours in a $80 \mathrm{Ti}$ Beckman rotor at $20^{\circ} \mathrm{C}$. 
Figure 4

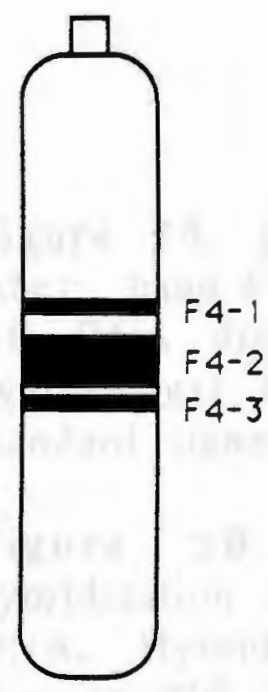

F4

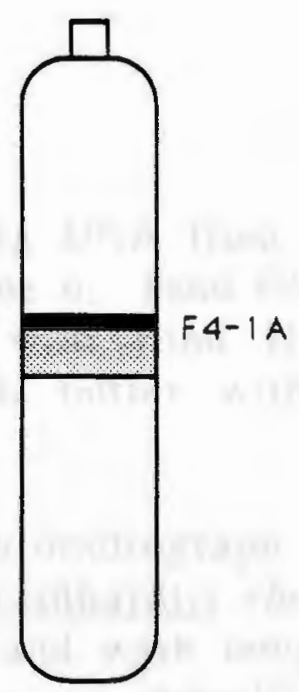

F 4- 1 (REPEAT)

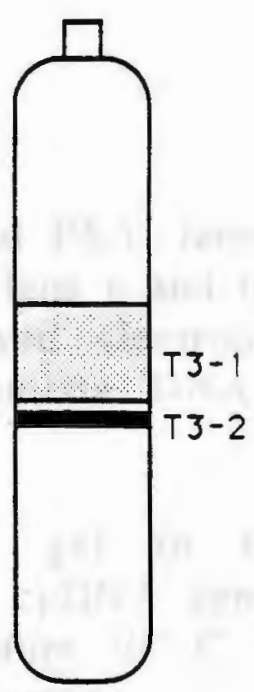

T3

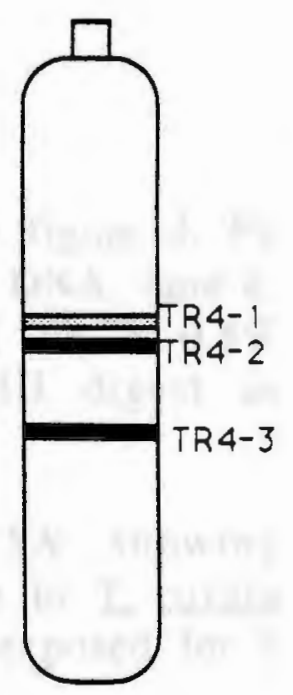

TR4

clone

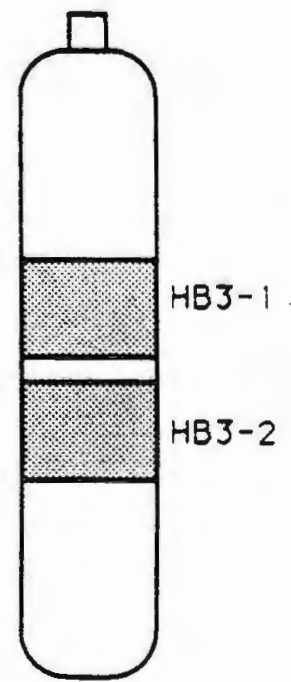

HB3

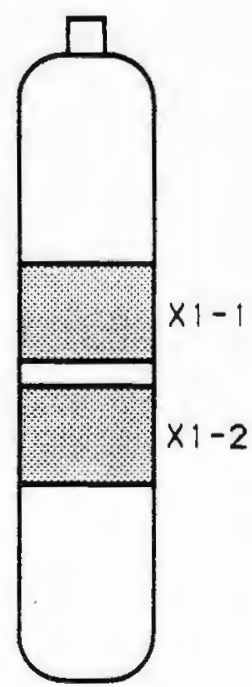

$x 1$

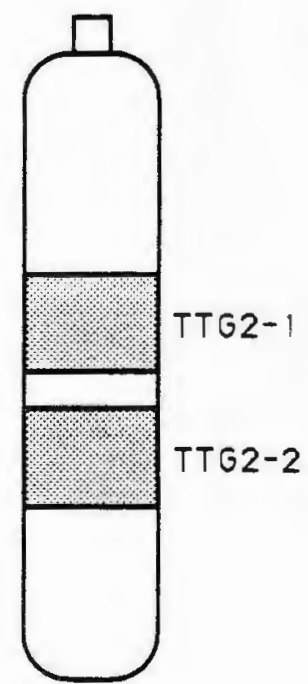

TTG2

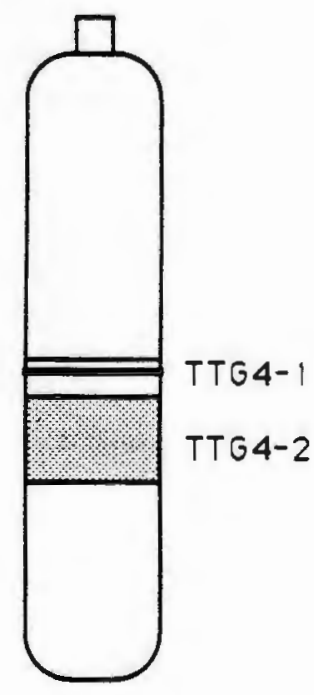

TTG4

clone 
Figure 5A. T. rotula DNA from band F4-1, lane a (see figure 4, F4 tube); band F4-2, lane b; band F4-3, lane $\mathrm{c}$ and total F4 DNA, lane d. All DNA digested with Hind III, and electrophoresed on a $0.8 \%$ agarose gel in TAE buffer with lambda DNA-Hind III digest as standard (lane L).

Figure 5B. Autoradiograph of gel in figure 5A showing hybridization of $\underline{C}$. reinhardtii $r b c L$ cpDNA gene probe to $\underline{T}$. rotula DNA. Hybridiztion and wash temperature $50^{\circ} \mathrm{C}$. Film exposed for 6 days at $-80^{\circ} \mathrm{C}$ using two intensifier screens. 
Figure 5

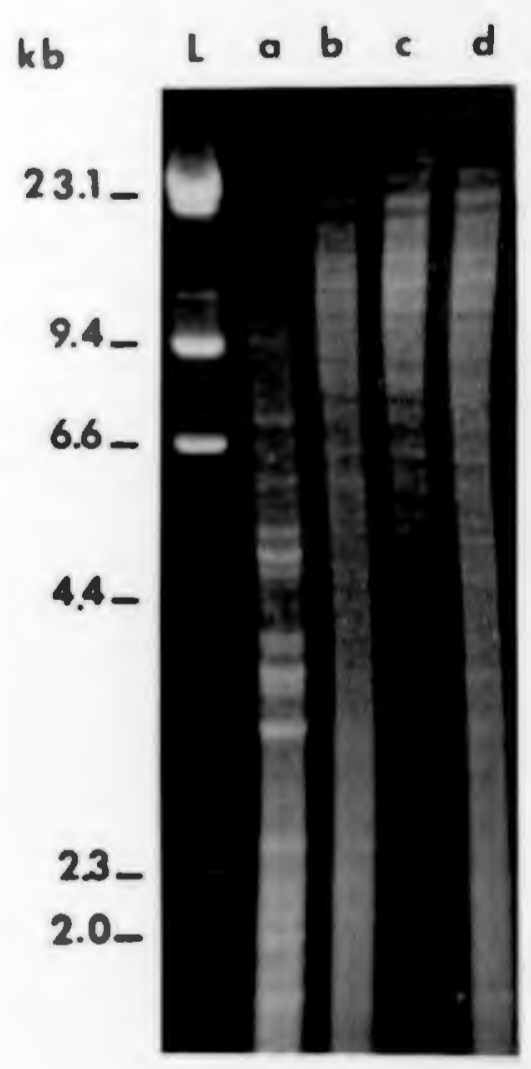

A

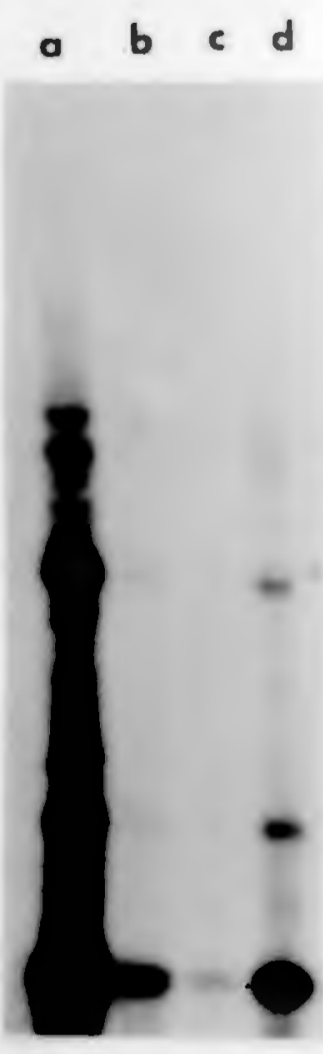

B 
Figure 6. T. rotula cp DNA (F4-1 band from CsCl-Hoechst dye gradient) digested with Pst I and electrophoresed on a $0.8 \%$ agarose gel (lane A). Hind III digest of lambda DNA in lane B as standard for size estimation. 
Figure 6

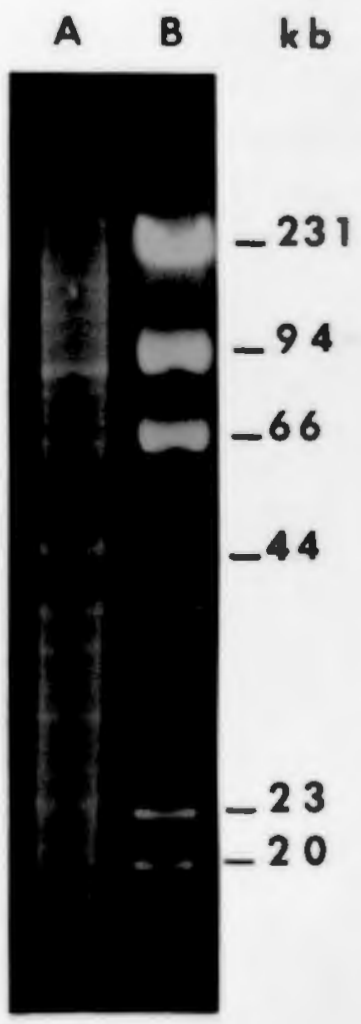


Figure 7: Autoradiographs of agarose gels containing digests of total diatom DNA probed with $\underline{\mathrm{C}}$. reinhardtii gene probe for $23 \mathrm{~S}$ rDNA cpDNA gene. Hybridization temperature was $65^{\circ} \mathrm{C}$ and wash temperatures were $65-90^{\circ} \mathrm{C}$. Blots were exposed to films for 8 hrs to several days at $-80^{\circ} \mathrm{C}$ with intensifier screen. Lanes identified as follows: Lane a, $\mathbf{T}$. nordenskioeldii clone Zud 2; lane b, $\underline{T}$. nordenskioeldii clone $\mathrm{X} 1$; lane $\mathbf{c}, \underline{\mathrm{T}}$. nordenskioeldii clone $\mathrm{HB} 3$; lane d, $\mathrm{T}$. gravida clone TTG2; lane e, $\mathrm{T}$ gravida clone TTG4. Hind III digest of lambda DNA used as standard. 

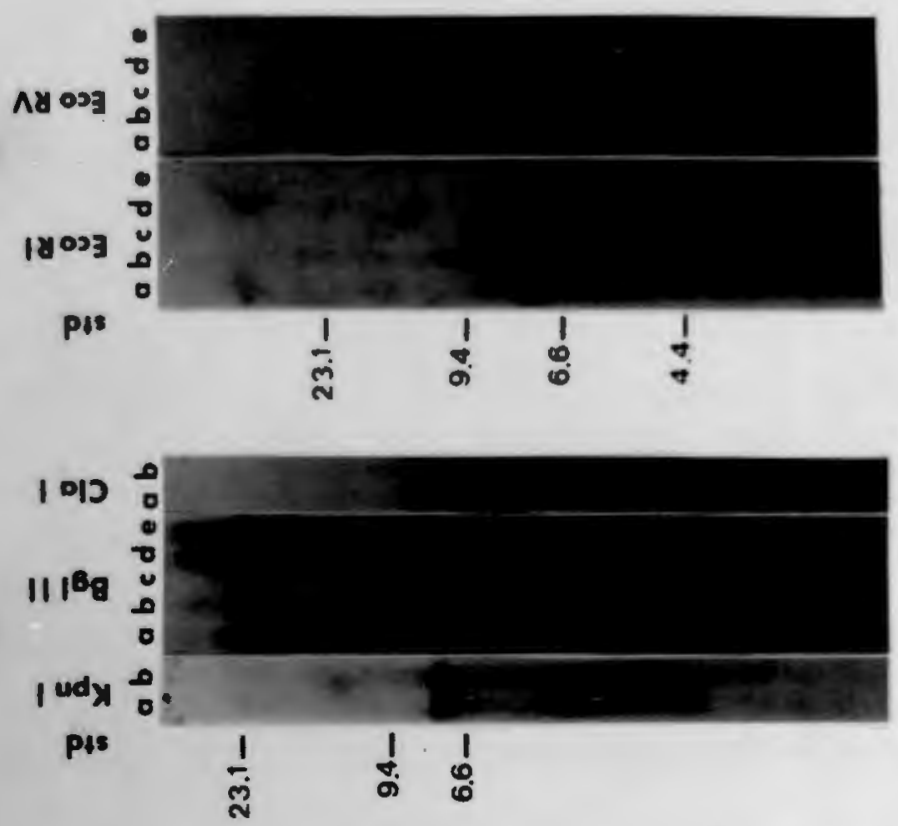

อ

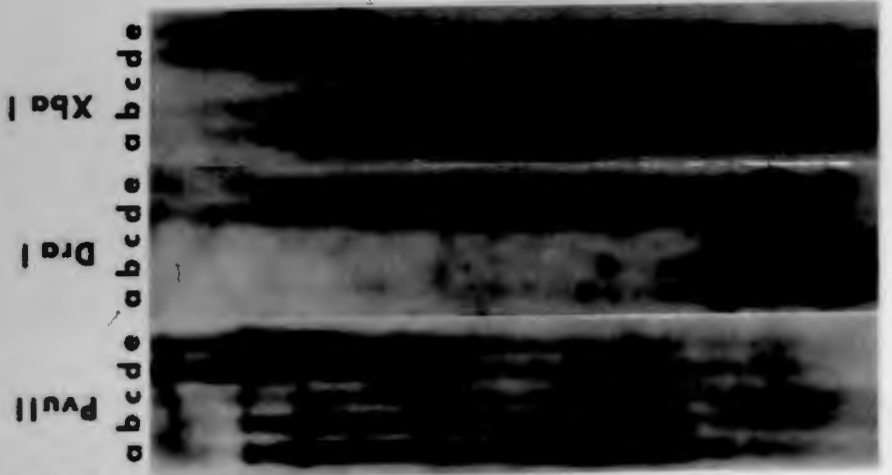

P4s

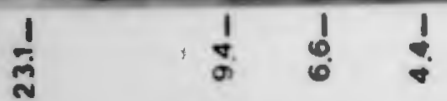

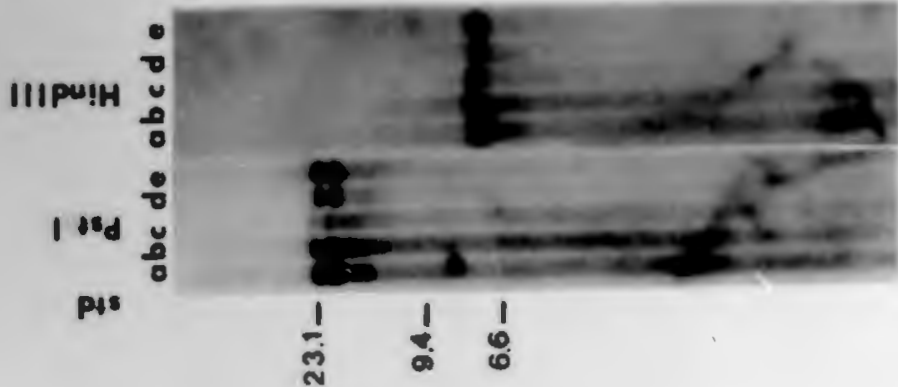


Figure 8: Autoradiographs of agarose gels containing digests of total diatom DNA probed with $\underline{C}$. reinhardtii gene probe for $r b c L$ cpDNA gene. Hybridization temperature was $65^{\circ} \mathrm{C}$ and wash temperatures were $65-90^{\circ} \mathrm{C}$. Blots were exposed to films for $8 \mathrm{hrs}$ to several days at $-80^{\circ} \mathrm{C}$ with intensifier screen. Lanes identified as follows: Lane a, T. nordenskioeldii clone Zud 2; lane b, T. nordenskioeldii clone $\mathrm{X} 1$; lane $\mathbf{c}, \underline{\mathrm{T}}$ nordenskioeldii clone $\mathrm{HB} 3$; lane $\mathbf{d}, \underline{\mathrm{T}}$ gravida clone TTG2; lane e, T. gravida clone TTG4. Hind III digest of lambda DNA used as standard. 

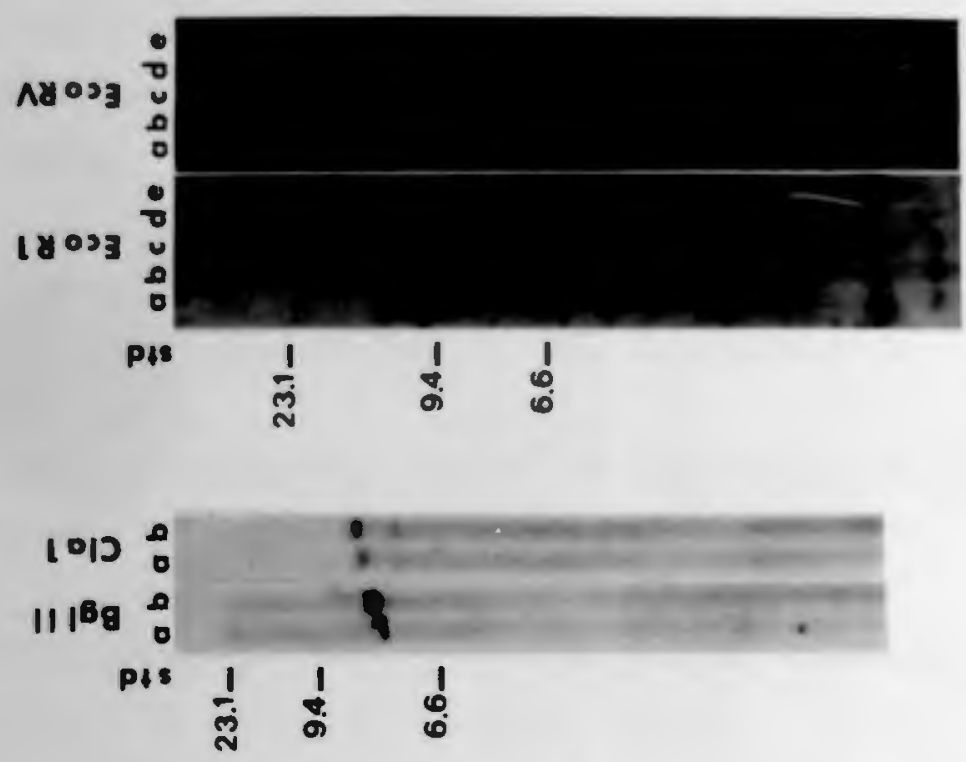

$\infty$
2
0
0
0
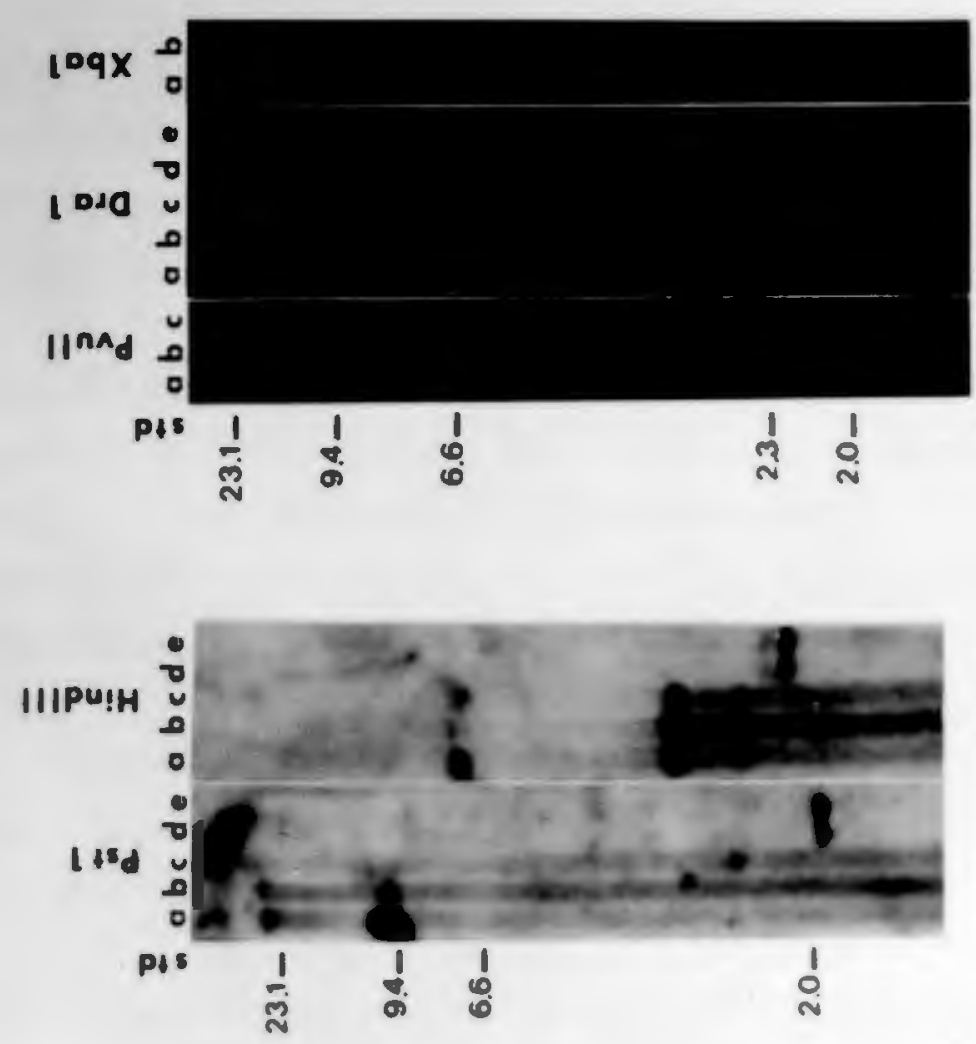


\section{BIBLIOGRAPHY}

Aldrich, J. and R. Cattolico (1981) Isolation and characterization of chloroplast DNA from the marine chromophyte, Olisthodiscus luteus: Electron microscopic visualization of isomeric molecular forms. Plant Physiol. 68. 641-647.

Aldrich, J., S. Gelvin and R. Cattolico (1982) Extranuclear DNA of a chromophytic alga. Plant Physiol. 69. 1189-1195.

Allan, G., J. Lewin and P. Johnson (1972) Marine Polymers. IV Diatom Polysaccharides. Bot. Marin. 15. 102-108.

Bak, A. L., C. Christiansen and A. Stenderup (1970) Bacterial genome sizes determined by DNA renaturation studies. J. Gen. Micr. 64 . $377-380$.

Beattie, A., E. Hirst and E. Percival (1961) Studies on the metabolism of the Chrysophyceae: Comparitive structural investigations on leucosin (chrysolaminarin) separated from diatoms and laminarin from the brown algae. Biochem. J. 79. 531-537.

Bell, R. T. (1986) Thymidine incorporation and estimates of bacterioplankton production: are the conversion factors valid? The Third International Workshop on the Measurement of Microbial Activities. In: The Carbon Cycle in Aquatic Ecosystems. Utrecht (Netherlands). 31. 163-171.

Berger, S. and A. Kimmel, Eds. (1987) Guide to Molecular Cloning Techniques. Methods in Enzymology. 152. Harcourt, Brace and Jovanovich. 813 pages.

Bourne, C. M., E. F. Stoermer and J. D. Palmer (1987) Cyclotella chloroplast genome analysis. J. Phyc. 23s.13. 
Bradford, M. (1976) A rapid and sensitive method for the quantitation of microgram quantities of protein utilizing the principle of protein-dye binding. Anal. Biochem. 72. 248-254.

Britten, R.J., D.E. Graham, and B.B. Neufeld (1974) Analysis of repeating DNA sequences by reassociation. In: Methods in Enzymology. 29. Academic Press, NY. 363-416.

Brooks, J. (1987) Properties and uses of restriction endonucleases. In: Guide to Molecular Cloning Techniques. Methods in Enzymology. 152. Berger, S. and A. Kimmel, Eds. Academic Press. Orlando.113-129.

Cavalier-Smith, T. (1982) The origins of plastids. Biol. Linnean Soc. 17. $289-306$.

Cavalier-Smith, T. (1986) The kingdom Chromista: origin and systematics. Progr. Phycol. Res. 4. 309-347.

Chin-Leo, G. and D. L. and Kirchman (1990) Unbalanced growth in natural assemblages of marine bacterioplankton. Mar. Ecol. Prog. Ser. 63. $1-8$.

Cleve, P. T. (1896) Diatoms from Baffin's Bay and Davis Strait. Bihang Till K. Svenska Vet.-Akad. Handlingar. Band 22 Afd.III (4). 3-22.

Coleman, A. (1985) Diversity of plastid DNA configuration among classes of eukaryotic algae. J. Phcol. 21.1-16.

Dalmon, J., S. Loiseaux and S. Bazetoux (1983) Heterogeneity of plastid DNA of two species of brown algae. Plant Sci.

Letters. 29. 243-253. 
Dodge, J. (1973) The Fine Structure of Algal Cells. Academic Press. 220 pages.

Dubois, M., K. A. Gilles, J. K. Hamilton, P. A. Rebers and F. Smith (1956) Colorimetric method for determination of sugars and related substances. Anal. Chem. 28 (3). 350-356.

Edelman, M. (1975) Purification of DNA by affinity chromatography: removal of polysaccharide contaminants. Anal. Biochem. 65. 293-297.

Edelman, M., J. Swinton, J. A. Schiff, H. T. Epstein and B. Zeldin (1967) Deoxyribonucleic acid of the blue-green algae (Cyanophyta). Bacteriol. Rev. 31 (4). 315-331.

Eppley, R.W., F.M.H. Reid, and J.D.H. Strickland (1970) The ecology of the plankton off La Jolla, California in the period April through September, 1967. Part III. Estimates of phytoplankton crop size, growth rates, and primary production. Bull Scripps Inst. Oceanogr. 17. 33-42.

Fain, S. (1987) Phylogenetic studies of the Laminariales utilizing chloroplast DNA restriction fragment analysis (abstract). J. Phycol. 23s. 13.

Fain, S., L. Druehl and D. Baillie (1988) Repeat and single copy sequences are differentially conserved in the evolution of kelp chloroplast DNA. J. Phycol. 24. 292-302.

Feinberg, A. P. and B. Vogelstein (1983) A Technique for radiolabeling DNA restriction endonuclease fragments to high specific activity. Anal. Biochem. 132. 6-13.

Florkin, M. (1966) A Molecular Approach to Phylogeny, Elsevier publishing Co., New York, 176 pages. 
Fuhrman, J. A. and F. Azam (1982) Thymidine incorporation as a measure of heterotrophic bacterioplankton production in marine surface waters: evaluation and field results. Mar. Biol. 66. $109-120$.

Goff, L. and A. Coleman (1988) The use of plastid DNA restriction endonuclease patterns in delineating red algal species and populations. J. Phycol. 24. 357-368.

Guillard, R. and J. Ryther (1962) Studies of marine planktonic diatoms. I. Cyclotella nana Hustedt, and Detonula confervacea (Cleve) Gran. Can. J. Microbiol. 8. 229-239.

Handa, N. (1969) Carbohydrate metabolism in the marine diatom Skeletonema costatum. Mar. Biol. 4(3). 208-214.

Hasle, G.R. (1968) The valve processes of the centric diatom genus Thalassiosira. Nytt. Mag. Bot. 15. 193-201.

Hasle, G.R. (1976) The biogeography of some marine phytoplankton diatoms. Deep-Sea Res. 23. 319-338.

Hasle, G.R. (1978) Some Thalassiosira species with one central process (Bacillariophyceae). Norw. J. Bot. 25. 77-110.

Hasle, G.R., B.R. Heimdal and G.A. Fryxell (1971) Morphologic variability in fasciculated diatoms as exemplified by Thalassiosira tumida (Janisch) Hasle, comb. nov., Antarctic Res. Ser. 17, 313-333.

Hermann, R., H. Palta and K. Kowallik (1980) Chloroplast DNA from three archegoniates. Planta. 148. 319-327.

Holm-Hansen, O. (1969) Algae: Amounts of DNA and organic carbon in single cells. Science. 163. 87-88. 
Holm-Hansen, O., W. H. Sutcliffe and J. Sharp (1968) Measurement of Deoxyribonucleic acid in the ocean and its ecological significance. Limnol. Oceanogr. 13. 507-514.

Kirk, J. (1983) Light and photosynthesis in aquatic ecosystems. Academic Press. 345 pages.

Kowallik, K. (1990) The plastid genomes of two centric diatoms, Odontella sinensis and Coscinodiscus granii (Abstract).The Eleventh International Symposium on Living and Fossil Diatoms. San Fransisco.

Lebour, M. (1930) The Planktonic Diatoms of Northern Seas. Roy. Soc. London. 116. 253 pages.

Makarova, I.V. (1980) Principles of the systematics of Thalassiosira Cleve and the significance of its taxanomic characters, In: The Proceedings of the Sixth Annual Diatom Symposium. 1-13.

Maniatis, T., E. F. Fritsch and J. Sanbrook (1983) Molecular Cloning. A Laboratory Manual. Cold Spring Harbor Loaboratories. 545 pages.

Manuelidis, L. (1977) A simplified method for preparation of mouse satellite DNA. Analyt. Biochem. 78. 561-568.

Mayr, E. (1970) Populations, Species, and Evolution. Belknap Press, Cambridge, MA. 453 pages.

McCoy, W. F. and B. H. Olson (1985) Fluorometeric determination of the DNA concentration in municipal drinking water. Appl. environ. Microbiol. 49. 811-817.

Meunier, A. (1910) Microplankton des mers de Barents et de Kara. Duc. d'Orleans, Camp. Arct. de 1907. 1-355. 
Murphy, L.S. and R.R.L. Guillard (1976) Biochemical taxonomy of marine phytoplankton by electrophoresis of enzymes. I. the centric diatoms Thalassiosira pseudonana and $\mathrm{T}$. fluviatilis. J. Phycol. 12. 9-13.

Murray, M. and W. Thompson (1976) Contaminants affecting plant DNA reassociation. Carnegie Institiution of Washington annual report.

Murray, M. and W. Thompson (1980) Rapid isolation of high molecular weight plant DNA. Nuc. Acids Res. 8 (19). 4321 4325 .

Nei, M. and W. Li (1979) Mathematical model for studying genetic variations in terms of restriction endonucleases. Proc. Natl. Acad. Sci., USA. 76. 5269-5273.

Olsen, J. (1990) Nucleic acids in algal systematics. J. Phycol. 26. 209-214.

Paasche, E. (1961) Notes on the phytoplankton from the Norwegian Sea. Bot. Mar. II (3/4). 197-214

Palmer, J. (1985a) Comparative organization of chloroplast genomes. Ann. Rev. Genet. 19. 325-354.

Palmer, J. (1985b) Evolution of chloroplast and mitochondrial DNA in plants and algae. In: Monographs in Evolutionary Biology: Molecular Evolutionary Genetics. MacIntyre, R., Ed. Plenum, New York. 131-240.

Palmer, J. (1986) Isolation and structural analysis of chloroplast DNA. In: Methods in Enzymology. Harcourt, Brace and Javonavich. 118. 167-186. 
Palmer, J. (1987) Chloroplast DNA evolution and biosystematic uses of chloroplast DNA variation. Nat. Hist. 130s. 6-29.

Palmer, J. and D. Zamir (1982) Chloroplast DNA evolution and phylogenetic relationships in Lycopersicon. Proc. Natl. Acad. Sci. USA. 79. 5006-5010.

Paul, J. H. and W. H. and Jeffrey (1985) Particulate DNA in subtropical oceanic and estuarine planktonic environments. Mar. Biol. 90. 95-101.

Paul, J. H. and X. Carlson (1984) Genetic material in the marine environment: importance of bacterial DNA. Limnol. Oceanogr. 29. (1091-1097):

Raleigh, E., S. Berger, and A. Kimmel (1987) Restriction and modification in vivo by Escherichia coli K12. In: Guide to Molecular Cloning Techniques. Methods in Enzymology. 152. Harcourt, Brace and Jovanovich. 813 pages.

Rochaix, J. Edelman, M. (1982) Isolation of chloroplast DNA from Chlamydomonas reinhardtii. In: Methods in Chloroplast Molecular Biology. Elsevier Biomedical Press. 542 pages.

Rothschild, L. and P. Heywood (1987) Protistan phylogeny and chloroplast evolution: conflicts and congruence. Prog. Protist. 2.1-68.

Southern, E. (1975) Detection of specific sequences amoung DNA fragments separated by gel electrophoresis. J. Mol. Biol. 98. 503-506.

Stabile, J. (1988) Personal Communication.

Stabile, J., J. Gallagher and E. Wurtzel (1990) Intraspecific variation in the chloroplast DNA of the marine diatom Skeletonema 
costatum (Abstract). The Eleventh International Symposium on Living and Fossil Diatoms. San Fransisco, CA.

Strathman, R. R. (1967) Estimating the organic carbon content of phytoplankton from cell volume or plasma volume. Limnol. and Oceanogr. 12. 411-418.

Sytsma, K. and L. Gottlieb (1986) Chloroplast DNA evolution and phylogenetc relationships in Clarkia sect. Peripetasma (Onagraceae). Evol. 40. (6): 1248-1261.

Sytsma, K. and B. Schaal (1985) Phylogenetics of the Lisianthius skinneri (Gentianaceae) species complex in Panama utilizing DNA restriction fragment analysis. Evol. 39. (3): 594-608.

Syvertsen, E. (1977) Thalssiosira rotula and T. gravida: Ecology and Morphology. Nova Hed. Beih 54. 99-112.

Syvertsen, E. (1984) Thalassiosira hispida sp nov., a marine planktonic diatom. Proceedings of the Eighth International Diatom Symposium. 33-42.

Wahl, G., S. Berger and A. Kimmel (1987) Molecular Hybridization of immobilized nucleic acids: theoretical concepts and practical considerations. In: Guide to Molecular Cloning Techniques. Methods in Enzymology. 152. Harcourt, Brace and Jovanovich. 399-407.

Whatley, J., P. John and F. Whatley (1979) From Extracellular to intracellular: the establishment of mitochondria and chloroplast DNA in plants. Proc. Natl. Acad. Sci. USA. 81. 1946-1950. 